\title{
Institutional Reforms Debate and FDI Flows to MENA Region: Does One 'Best' Fit All?
}

\author{
Wasseem Michel Mina*
}

September 2011

\begin{abstract}
The paper revisits the policy debate on institutional reform approaches to property rights protection and empirically examines it in the context of FDI flows to the Middle East and Northern Africa region (MENA).Using panel data on 11 MENA countries for the period 1991-2007 and adopting feasible generalized least squares estimation methodology, the paper finds a positive influence of improvement in the risk of investment expropriationin non-Gulf Cooperation Council (GCC) MENA countries and of bilateral investment treaties (BITs) in GCC countries. The joint influence of domestic institutional functions and BITs is positive in specifications containing investment expropriation risk and government stability in non-GCC MENA countries, and corruption in GCC countries. Results have important policy implications for the institutional reform approach to be adopted.
\end{abstract}

Keywords: property rights protection, bilateral investment treaties, foreign direct investment, institutional reforms, MENA, heterogeneity

JEL classification:F21, K33, O16, O17, O19

\section{Copyright (C) UNU-WIDER 2011}

*United Arab Emirates University, Department of Economics and Finance, and Research Associate, Economic Research Forum, email: wmina@uaeu.ac.ae.

This study has been prepared within the UNU-WIDER project on New Directions in Development Economics.

UNU-WIDER gratefully acknowledges the financial contributions to the research programme by the governments of Denmark (Royal Ministry of Foreign Affairs), Finland (Ministry for Foreign Affairs), Sweden (Swedish International Development Cooperation Agency-Sida) and the United Kingdom (Department for International Development-DFID).

ISSN 1798-7237 ISBN 978-92-9230-417-1 


\section{Acknowledgements}

Part of this research was conducted and presented within UNU-WIDER's research seminar serieswhile the author was a UNU-WIDER visiting scholar in summer 2009. UNU-WIDER's support and hospitality as well as the financial support of the Faculty of Business and Economics at the UAE University (through Summer Research Grant program) are gratefully acknowledged. Anearlier version of this working paper is included in the International Studies Program's working paper series at the Andrew Young School of Policy Studies, Georgia State University.

The author would like to thank, without implications, Augustin Fosu(UNU-WIDER, University of California, Berkeley,and University of Manchester), Wim Naude (UNUWIDER and Maastricht School of Management), Jan-Erik Antipin, Luc Christiaensen, Alisa DiCaprio, Imed Drine, and Lisa Winkler (UNU-WIDER), Paul Alagidede (University of Sterling),AleksanderSurdej (Cracow University of Economics),Jorge Martinez-Vazquez (Georgia State University), Magda Kandil (IMF and Egyptian Center for Economic Studies),SuutDogruel (Marmara University), Jeffrey Nugent (University of Southern California), Mine Cinar (Loyola University Chicago), Hassan Aly (African Development Bank and Ohio State University) and participants at the Nordic Conference on Development Economics (2010), the African Econometric Society's 15th Annual Conference on Econometric Modeling for Africa (2010), the 3rd Summer Research Day of the Faculty of Business and Economics at the UAE University (2010), and participants at the Middle East Economic Association Meetings (2011) for useful comments and suggestions. The author would like also to thank Lay Poh Allonen (UNU-WIDER) and Ahmed Taha (UAE University) for excellent library services.

The World Institute for Development Economics Research (WIDER) was established by the United Nations University (UNU) as its first research and training centre and started work in Helsinki, Finland in 1985. The Institute undertakes applied research and policy analysis on structural changes affecting the developing and transitional economies, provides a forum for the advocacy of policies leading to robust, equitable and environmentally sustainable growth, and promotes capacity strengthening and training in the field of economic and social policy making. Work is carried out by staff researchers and visiting scholars in Helsinki and through networks of collaborating scholars and institutions around the world.

www. wider.unu.edu publications@wider.unu.edu

UNU World Institute for Development Economics Research (UNU-WIDER)

Katajanokanlaituri 6 B, 00160 Helsinki, Finland

Typescript prepared by Lisa Winkler at UNU-WIDER

The views expressed in this publication are those of the author(s). Publication does not imply endorsement by the Institute or the United Nations University, nor by the programme/project sponsors, of any of the views expressed. 


\section{Introduction}

Institutions are defined as the set of rules governing human behaviour (North 1991). They include both formal and informal rules. Formal rules are legal in nature, and include constitutions, laws, and regulations created and enforced by the government, in response to individuals' needs to organize interactions in society. Informal rules are social in nature, and include traditions and customs, influenced by cultures and beliefs, and evolve with the development of society and human behaviour.

Institutions play an important role in supporting markets and transactions by protecting property rights, enforcing contracts, and facilitating collective action to provide physical and organizational infrastructure (Dixit 2009). They create order, reduce uncertainty in the exchange of goods and capital, and help determine the transaction and production costs and thus the feasibility and profitability of engaging in economic activity (North 1991).

Among the positive outcomes of good institutions is the promotion of integration into the world economy (Rodrik 2008). In promoting integration into the world economy, capital flows constitute one important integration channel. Property rights protection (PRP) is widely believed and has been empirically found to encourage capital flows and provide incentives for investment and capital exchange.

In empirically examining the influence of domestic institutions on capital flows, empirical studies have focused mostly on domestic PRP institutional functions.1,2 These studies have used indicators of institutional functions quality, which assess actual performance against industrialized countries' first best performance.

This assessment approach has been adopted despite the diverging social and political norms between developing and emerging market economies on the one hand, and developed economies on the other. Such approach implies that institutional reforms, if decided on, should in principle bring convergence of domestic institutional functions performance in developing and emerging market economies to that in developed countries. It may also imply that in undertaking institutional reforms, developing and emerging market economies should adopt an 'orthodox' approach of reforming domestic institutions that is believed to achieve the first best, a point that is discussed further below.

The assessment of institutional function performance against industrialized countries' first best is understandable in light of the intensifying globalization over the past

1 By PRP institutional functions we refer to the outcomes of domestic institutions, mainly the legal and judicial systems and the government bureaucracy, which influence the PRP process. Examples of these functions are the issuance and the enforcement of laws, contracts and order; the restriction of government power to expropriate and extract rents; and the control of corruption.

2 See for example Alfaro et al. (2008), Asiedu (2006), Busse and Hefeker (2007), Daude and Fratzscher (2008), Daude and Stein (2007), Du et al. (2008), Faria and Mauro (2009), Kraay and Nehru (2006), Lane (2004), Mina (2006), Mina and Martinez-Vazquez (2006), Mishra and Dally (2007), Naude and Krugell (2007), and Wei (2000). 
quarter century and the growing importance of markets in resource allocation and conducting economic activity. Intensifying globalization and development of markets have required the adoption of common institutional functions and standards, similar to the adoption of a common language in communications, which facilitate trade and capital mobility.

Adopting an orthodox approach for institutional reforms, however, does not take into account a country's unique circumstance and the interaction with other institutional features within the country. This view is supported by Rodrik (2008), who argues that institutional reforms promoted, for example by the World Bank, IMF or WTO, presume the existence of a unique set of appropriate institutional arrangements the convergence to which is 'inherently desirable'. He also warns that the convergence to a first best practice does not 'consider potential interactions with institutional features elsewhere in the system' and advocates institutional reforms based on the theory of the second best instead. 3

Along the lines of the theory of the second best, many governments have signed bilateral investment treaties (BITs) in the presence of domestic institutional functions in order to strengthen PRP, either as complements or substitutes to their domestic (PRP) institutional functions. A BIT is a legal instrument under international law between two contracting countries, the aim of which is to establish clear, simple, and enforceable rules for the reciprocation of foreign investment protection from the risk of government expropriation in each other's country. It identifies the circumstances under which expropriation can take place and the associated compensation standards, and establishes investment dispute settlement mechanisms, which facilitate foreign investment in the presence of imperfect domestic PRP institutional functions.

Against the theoretical debate underlying institutional reforms, the paper empirically examines the validity of this debate to Middle East and North Africa (MENA) countries. The paper empirically examines the influence of the second best approach for PRP comprised of BITs and domestic institutional functions (as well as the interaction between them) on foreign direct investment (FDI) flows to the MENA region, while controlling for the traditional FDI determinants. The paper compares such influence to that of the first best approach comprised only of domestic institutional functions. MENA countries provide room for improvement in performance of a number of domestic institutional functions. The paper selects treaties entered into force with high-income OECD countries, constituting about one-third of the number of treaties entered into force by 11 high- and middle-income MENA countries, which aim to attract FDI flows. 4 MENA countries include both Gulf Cooperation Council (GCC) and non-GCC MENA countries.

3 Using Ghana and Vietnam as examples, Rodrik (2008) argues that despite the presence of commercial laws, courts are highly inefficient, costly to use, and potentially corruptible. In response, firms resort to relational contracting as an alternative, building long-term relationships with each other and sustaining cooperation through repeated interaction. Long-term relational contracting is regarded as a (better) informal substitute to the (weak) formal PRP institutions.

4 Sample countries comprise Algeria, Egypt, Morocco, and Tunisia from North Africa, Bahrain, Kuwait, Oman, Saudi Arabia, and UAE from the GCC region, in addition to Jordan and Syria. 
The paper uses panel data for the period 1991-2007 and adopts feasible generalized least squares methodology to account for heterogeneity. Autocorrelation, both within and across panels, is accounted for. Empirical evidence suggests no influence of domestic institutional functions in most model specifications. However, in the case of non-GCC MENA countries, an improvement in the risk of investment expropriation has a positive influence on FDI flows. The influence of BITs alone is hardly significant in economic and statistical size in non-GCC countries, but significant in GCC countries. The joint influence of domestic institutional functions and BITs, as well as the interaction between them is positive in specifications containing investment expropriation risk and government stability in non-GCC MENA countries, and corruption in the case of GCC countries.

Empirical evidence also shows that location factors are important determinants of FDI flows to MENA countries. In GCC countries oil prices and labour force attract FDI flows, while oil production and inflation discourage them. Trade openness on the other hand has a positive though statistically insignificant influence. In non-GCC countries labour force and trade openness play a positive and statistically significant role in attracting FDI flows. Similar to GCC countries, oil production has a negative but marginally significant influence, while oil price has no statistically significant influence unlike in GCC countries.

The paper contributes to the development economics, international capital flows, and economic policy literature(s) in three main respects. First, it revisits the conceptualization of and policy debate on institutional reform approaches in the development economics and economic policy literature, and empirically examines it in international capital flows context for the first time in the literature. Second, it regards PRP as a multidimensional process, which involves a set of inter-related domestic institutional functions serving this purpose. Third, stemming from an institutional reform perspective, the paper focuses on a group of MENA countries and decomposes them into natural resource-rich GCC countries and human resource-rich non-GCC MENA countries. Each of these two groups of countries has common characteristics. This approach adds depth to our understanding of regional policy reforms.

The paper proceeds as follows. Section 2 discusses the findings of the empirical literature on the influence of domestic institutional functions on capital flows, the influence of BITs on FDI, in addition to the determinants of FDI in the MENA region. Section 3 discusses the proliferation of BITs, and the performance of domestic institutional functions and FDI in the MENA region. Section 4 discusses the empirical model and the testable hypotheses. Section 5 discusses the data and empirical issues and the estimation methodology adopted. Sections 6 and 7 discuss the empirical results and robustness checks, respectively, while Section 8 concludes.

Lebanon has been excluded from the sample due to the civil war and political unrest, which have plagued the country until recently, and the absence of natural resources, an important explanatory variable in the empirical model. Libya and Qatar have been excluded due to missing observations on trade openness, as discussed further in Section 5. 


\section{Empirical literature survey}

In this section we discuss three strands of the empirical literature. The first strand is on the influence of domestic institutional functions on capital flows. The second strand is on the influence of BITs on FDI. While the first two sub-sections report the findings of the literature, the third strand is MENA region-specific and discusses the determinants of FDI in the region. 5

\subsection{Domestic institutional functions and capital flows}

The influence of domestic institutional functions on the different types of capital flows has been empirically examined in the capital flows literature. In the FDI literature it is found that better domestic institutional functions encourage FDI in different regions. Asiedu (2006) finds that less corruption, political stability, and legal system reliability promote FDI in Africa, a result that Naudé and Krugell (2007) share. Mishra and Daly (2007) reach similar results in examining FDI in host OECD and Asian countries. They find that the strength and impartiality of the legal system, popular observance of law, strength and quality of bureaucracy, and government stability have a direct effect on FDI. Focusing on US FDI in China, Du et al. (2008) recently examine the impact of economic institutions, including PRP and contract enforcement, on location choice among Chinese regions, and find that US multinationals prefer to invest in regions with better protection of intellectual property rights, lower degree of government intervention in business operations, lower level of government corruption, and better contract enforcement.

More generally in developing countries, Busse and Hefeker (2007) find that institutional functions, namely government stability, internal and external conflict, corruption and ethnic tensions, law and order, democratic accountability of government, and quality of bureaucracy, are highly significant determinants of FDI inflows. Daude and Stein (2007) find that better institutional functions have an overall positive effect on bilateral FDI. However, some institutional functions have more influence on FDI than others; these include government stability, law predictability, and quality of regulations and policies. Wei (2000) focuses solely on corruption and finds that corruption acts as a tax deterrent to bilateral FDI.

PRP institutional functions have an important influence on equity capital flows, i.e. both FDI and portfolio equity. In examining whether countries get more financially integrated through certain types of capital flows as opposed to others, Daude and Fratzscher (2008) find that portfolio investment, compared to FDI and debt securities, is by far the most sensitive to quality of institutional functions. Similarly Alfaro et al. (2008) find that low institutional quality is the leading factor in explaining the lack of capital flows from rich to poor countries - the Lucas Paradox. Exploring the determinants of countries' external capital structure, Faria and Mauro (2009) find that the share of FDI and portfolio equity in countries' total external liabilities is positively influenced by quality of institutional functions, as well as educational attainment and

5 There is another strand of the limited FDI literature on the MENA region which addresses its influence on growth (Kandil and Mirzaie 2009; Korgstup and Matter 2005; Omran and Bolbol 2003; Sadik and Bolbol 2001). This strand, however, is beyond the scope of the paper. 
natural resource abundance-better domestic institutional functions are said to tilt countries' capital structures towards equity and away from debt.

In the international debt literature, it has been found that better PRP institutional function increases the level and lengthens the maturity of international lending, and reduces the probability of financial crisis. Kraay and Nehru (2006) find that improvement in policies and quality of institutional functions largely reduces the probability of debt distress, and is roughly of the same order of magnitude as reductions in debt burdens. 6 Lane (2004) finds that better institutional function quality increases the level of external debt. ${ }^{7}$ Mina (2006) and Mina and Martinez-Vazquez (2006) show that better contract enforcement and institutional stability increase the level and lengthen the maturity of international lending a country can attract.

In summary there appears to be four main findings of the above empirical studies. First, the quality of domestic institutional functions positively influences capital flows. Second, better institutional function quality tilts countries capital structure towards equity and away from debt. Third, portfolio equity is more sensitive to institutional function quality than FDI. Fourth, from a geographical perspective the influence of domestic institutional functions on FDI has been examined in different regions with the exception of the MENA region.

The first and fourth findings are of special importance and relevance to this paper. The first finding lends major support to the first-best approach to institutional reforms typically called for by international organizations, such as the World Bank and IMF. The fourth finding clearly identifies a geographical gap in literature coverage, which this paper attempts to fill.

\subsection{BITs and FDI}

The influence of BITs on FDI has been examined in the FDI literature (Desbordes and Vicard 2009; Egger and Pfaffermayr 2004; Egger and Merlo 2007; Hallward and Driemeier 2003; Kerner 2009; Mina 2009; Neumayer and Spess 2005; Tobin and Rose-Ackerman 2006; UNCTAD 1998). This research question has been extended to a number of directions: the role of treaties in strengthening economic and political relationships (Desbordes and Vicard 2009); the nature of relationship between treaties and domestic institutions (being complements or substitutes) (Desbordes and Vicard 2009; Hallward and Driemeier 2003; Mina 2009; Neumayer and Spess 2005); the level of government commitment to PRP by signing or entering into force treaties (Egger and Pfaffermayr 2004; Egger and Merlo 2007; Kerner 2009; Mina 2009); the impact of treaties on FDI over time (Egger and Merlo 2007); and the impact of

6 They measure quality of policies and institutional functions using the World Bank's country policy and institutional assessment.

7 His measure of institutional quality is an average of government anti-diversionary practices index and the Sachs-Warner liberal policies index. The government anti-diversionary practices index is a weighted average of the International Country Risk Guide's law and order, bureaucratic quality, corruption, risk of expropriation, and government repudiation of contracts. The Sachs and Warner index measures the fraction of years (from 1950-94) that a country followed mainly liberal trade policies. 
treaties as proliferation across countries (Tobin and Rose-Ackerman 2006). We briefly survey below these studies keeping in mind first the impact on FDI and second the finer strand addressed. We leave for the footnotes the empirical model and estimation methodology adopted.

UNCTAD (1998) examines the impact of investment treaties on FDI using both time series and cross-section analyses. Time series analysis has been conducted using data over 11 years and 200 BITs signed between 14 home and 72 host countries. The study finds that investment treaties have a positive, albeit not a strong effect on FDI flows. However, BIT impact is most statistically significant for the share of a home country partner in a host country's total inflows, and for the share of a particular host country in a home country's total FDI outflows. The cross-section analysis of the study has found a positive impact of investment treaties on the absolute level of FDI flows and on FDI flows relative to GDP. The overall conclusion of the cross-section analysis is that investment treaties play a minor and secondary role in attracting FDI, while the leading determinant appears to be market size.

A similar conclusion is reached by Hallward-Driemeier (2003) in examining the impact of ratified BITs on bilateral FDI flows from 20 home OECD countries to 31 host developing countries over the period 1980-2000.8 She tests for the change over time in the property rights introduced with ratified BITs in three ways: (a) using a dummy variable that takes the value of 1 once a BIT has been ratified between a pair of source-host countries (the significance of the coefficient indicates the importance of the treaty), (b) using a dummy variable for a three-year post-ratification window to capture the time horizon over which a BIT might attract additional FDI, and (c) using a series of dummies for the year of ratification, and each year prior and postratification to see if there are consistent patterns across country pairs. She finds both negative and little positive impact of investment treaties on FDI in countries, and argues that this impact is possibly obscured by other changes occurring between the two contracting partners over time, such as lowering trade barriers, the increased knowledge of conducting business in the host country, and ratification of a tax treaty. She also finds that BITs complement rather than substitute for strong domestic institutions, and are more "effective in settings of higher institutional quality and where institutions are already being strengthened.' Accordingly, she argues that

This undermines a central rational for some of the less developed countries that enter into these agreements hoping to bypass the need to strengthen property rights and institutions more generally. Put differently, if host countries are committed to trying to attract more

8 The dependent variables of the different empirical model specifications are FDI flows, FDI flows relative to GDP, and the share of home country FDI flows in total host country flows. The explanatory variables in the empirical model include (a) BITs ratification date, (b) the size of the source and host countries, (c) the host country's GDP per capita, (d) inflation rate as a proxy for macroeconomic stability, (d) trade relative to GDP as a measure of trade openness, (e) the gap in average years of education between the source and host pairs, and (f) two dummies to capture the effects of the enormous political and economic changes in Eastern Europe and the former Soviet Union and the ratification of NAFTA. Fixed effects and instrumental variables methodologies are adopted in econometric estimation. 
FDI, BITs have not provided a short-cut from the need to implement broader reforms of domestic institutions (ibid.: 21-2).

More recent studies have found a positive impact of BITs on FDI. Distinguishing between signed and ratified BITs, Egger and Pfaffermayr (2004) find that both signed and ratified treaties exert a significant positive impact on the stock of outward FDI of 19 home OECD countries into 54 host countries (both OECD and non-OECD) for the period 1982-97.9 However, the impact of ratified treaties is higher than that of signed treaties. Similarly Neumayer and Spess (2005) find that BITs have a significant positive impact on FDI flows to 119 developing countries for a longer time period (1970-2001). 10 Also Tobin and Rose-Ackerman (2006), in studying the impact of BITs contracted between home OECD countries and host developing countries during the period 1980-2003, find that the number of treaties contracted has a positive impact on FDI in subsequent periods but their marginal impact diminishes as the number of globally contracted BITs increases. Additionally, they find that a stronger political environment for investment and a better local economic environment are complements to BITs.

Accounting for the long-run dynamic effect of BITs on FDI and adopting a firstdifferenced generalized method of moments (GMM) estimator, Egger and Merlo (2007) use bilateral FDI stocks covering 24 home and 28 host OECD and transition countries in the period 1980-2001.11 They find that the long-run impact of BITs on FDI is nearly double the short-run effect.

Focusing on the oil abundant GCC countries and arguing that the rationale for contracting BITs seems controversial and goes beyond attracting FDI to strengthening bilateral economic and political relationships, Mina (2009) finds that BITs contracted

9 The dependent variable in their study is outward FDI stocks in constant 1995 US\$. The explanatory variables are (a) absolute bilateral country size (sum of GDP in home and host countries), (b) similarity in bilateral country size, (c) bilateral difference in the endowment ratio of the skilled to unskilled labour (relative factor endowments), (d) BITs signed, (e) BITs ratified, (f) an interaction term between relative factor endowments and distance, $(\mathrm{g})$ an interaction term between relative factor endowments and the difference in bilateral country size, and (h) an interaction term between relative factor endowments and absolute bilateral country size. They use a fixed effects model in their estimation.

10 The dependent variable in their study is FDI flows in constant 1996 US\$. The explanatory variables are (a) the number of BITs a developing country has signed with OECD countries weighted by the share of outward FDI flow the OECD country accounts for relative to total world outward FDI flows, (b) per capita income (in log form), (c) population size (in log form), economic growth rate, (e) WTO membership, (f) number of bilateral trade agreements concluded with the US, EC/EU, or Japan, (g) inflation rate, and (h) measures of institutional quality, which include Henisz's (2000) political constraints and the International Country Risk Guide's investment profile, government stability, law and order, and the composite political risk indices.

11 The dependent variable is the bilateral outward FDI stocks (in log form). The explanatory variables are (a) the first lag of the dependent variable, (b) a dummy variable that takes a value of 1 starting the year a BIT is ratified among two countries, (c) the sum of GDP in host and home countries (in $\log$ form), (d) the relative size of GDP in home to host country (in log form), (e) the relative tertiary school enrollment shares of home to host country (in log form), and (f) a time trend. They adopt a first-differenced GMM estimator. 
with high-income non-OECD countries have a positive influence and are more influential on FDI stocks than domestic institutions, contrary to Hallward-Driemeier (2003). 12 On the other hand, BITs contracted with OECD and upper/middle-income countries have a surprisingly negative influence, and seem to be dominated by the significantly positive influence of domestic institutions on FDI similar to HallwardDriemeier (2003).

Focusing on the political rationale of BITs, Desbordes and Vicard (2009) argue that foreign investors are likely sensitive to the quality of interstate political relationships, which negatively affects government expropriation of investment. In this respect BITs offset interstate political tensions. Using a gravity FDI model to empirically examine the impact of BITs on bilateral FDI stocks between 30 OECD countries and 62 OECD and non-OECD countries in 1991-2000, they find that the quality of interstate political relations significantly increases FDI, BITs have a positive effect on FDI stocks especially when interstate political relationships are tense, and the effectiveness of treaties increases with the quality of domestic governance suggesting that both domestic institutions and BITs are complements. 13

Observing the puzzle that BITs increase aggregate FDI flows despite the absence of evidence on increased investment by protected investors, Kerner (2009) offers explanations of the mechanisms through which BITs impact FDI based on international relations theories. He argues that ratified treaties can tie the government's hands through ex post costs of violating treaties or send a signal that the government observes investors' property rights and is therefore trustworthy. $14 \mathrm{He}$

12 The dependent variable is the stock of real FDI relative to GDP, while the explanatory variables are (a) the total number of BITs contracted, (b) domestic institutions measured by the International Country Risk Guide's political risk index, (c) relative oil production, (d) market size measured by real GDP, (e) the general price level measured by the GDP deflator, (f) human capital proxied by secondary education enrollment relative to total school enrollment, and $(\mathrm{g})$ trade openness measured by merchandise imports. She uses panel data for the period 1984-2002 and instrumental variables estimation methodology to deal with endogeneity associated with reverse causal relationship between FDI on the one side, and external commitment mechanisms and domestic institutions on the other.

13 The dependent variable of the empirical model is bilateral FDI stock, while the explanatory variables are (a) GDP in the home country, (b) GDP in the host country, (c) GDP per capita in the home country, (d) GDP per capita in the host country, (e) bilateral distance, (f) gravity-specific dummies (contiguity and common language), (g) measure of the quality of domestic institutions in the host country, (h) proxy of the quality of interstate political relations, (i) a dummy for BITs, (j) an interaction term between BITs and the quality of domestic institutions in the host country, and (k) an interaction terms between BITs and interstate political relationships between the home and host countries. Poisson quasi maximum likelihood estimator (QMLE) is used to deal with the problem of accounting for zeros in the dependent variable which is common to log specifications of gravity models. QMLE is also consistent in the presence of heteroskedasticity.

14 Elkins et al. (2006) perceive BITs tying the hands of the government by (a) specifying the contractual obligations of the host government regarding the protection of foreign investments, (b) explicitly involving the home country's government thereby increasing the possibility of severing diplomatic relations as the foreign investor's home government gets involved in case of investment disputes, (c) enhancing contract enforcement and awarding compensation to foreign investors whenever expropriation is established through the dispute settlement body, and (d) increasing the reputation costs in the eyes of other non-treaty countries and investors. 
tests two main hypotheses. First, BITs tie governments' hands and therefore encourage FDI flows from protected investors. Second, BITs send widely a credible PRP signal, and therefore encourage FDI flows from both protected and unprotected investors by the treaty.

In summary three main useful messages arise from these empirical studies. First, the influence of BITs depends on the degree of government commitment to PRP, and is surprisingly not always positive. Second, domestic institutional functions can complement or substitute BITs in attracting FDI. Third, the impact of BITs tends to diminish as the number of treaties contracted globally increases. None of these studies however has taken a developmental perspective at BITs vis-á-vis domestic institutional functions, and raised the question of how can policy makers improve PRP. Should countries reform domestic institutional functions independently of contracting BITs - a first best approach? Or should countries rather pursue institutional reforms by having both of them jointly - a second best approach? These two policy questions motivate and underlie the hypotheses examined in this paper.

\subsection{FDI determinants in MENA region}

The literature on FDI determinants in the MENA region is fairly recent and limited. Explaining the stagnating FDI flows (relative to GDP) to the MENA region between 1985 and 1999, Chan and Gemayel (2004) focus on investment risk. They find that investment risk instability has been a key determinant in discouraging FDI into the region; investment risk stability increases the rate of return certainty, and becomes more desirable as investment risk increases. 15 In the European Union and North America, investment risk, as opposed to investment risk instability, explain FDI inflows.

Going beyond investment risk to market fundamentals, Onyeiwu (2003) examines whether the determinants of FDI flows affect the MENA region differently from other developing countries. Using data on 51 developing countries including 10 MENA countries for the period 1975-99, he finds that trade openness and privatization increase FDI flows to MENA, while corruption and bureaucratic red tape reduce flows to the region. Traditional FDI determinants, such as the rate of return on investment, infrastructures, economic growth, and inflation, have no effect. 16

15 The dependent variable is the ratio of FDI flows to GDP, while the explanatory variables are (a) lagged dependent variable, (b) the mean of FDI to GDP ratio during the period, (c) risk index. They use three types of risks separately: economic, financial, and political, and examine the influence of the level, standard deviation, and interquartile range of the risk index. They used data on 19 MENA countries for the period 1990-99 and random effects dynamic model in estimation.

16 The dependent variable is net FDI as a percentage of GDP, while the explanatory variables are (a) the rate of return on investment measured by the log of the inverse of the real GDP per capita, (b) openness of the economy measured by the sum of imports and exports relative GDP, (c) political rights measured by Freedom House's Index of Political Freedom, (d) infrastructure proxied by the number of telephone lines per 1,000 people, (e) natural resource availability measured by the ratio of fuel exports to total exports, f) corruption and bureaucratic red tape proxied by government expenditure relative to GDP, (g) human capital measured by secondary school enrollment relative to the population in secondary school age, (h) and macroeconomic fundamentals, which include (i) 
Earlier Kamaly (2000) examines the factors influencing FDI flows to the MENA region using data on 11 countries-Algeria, Egypt, Kuwait, Lebanon, Libya, Morocco, Oman, Syria, Tunisia, Turkey, and Yemen - for the period 1990-99. He finds that FDI is highly persistent, and that real GDP growth rate has a positive influence on FDI in both the short- and long-run. $17 \mathrm{He}$ also introduces other explanatory variables into the regression model - the rate of change and variability of the nominal exchange rate, democracy, the ratio of M2 to GDP as a measure of financial deepening, and creditworthiness variables. 18 However, none of the coefficients of these variables are statistically significant.

Also focusing on fundamentals was Hisarciklilar et al. (2006) who examine the influence of market potential on the stock of FDI in 18 MENA countries over the period 1980-2001.19 Market potential includes both domestic and foreign markets. They find that domestic market size and intra-MENA region trade opportunities have a positive influence on the stock of inward FDI, and conclude that FDI in the MENA region is market- as opposed to resource-seeking.

FDI in natural resource-rich MENA countries has also attracted attention. Mina (2007) studies the location determinants of FDI flows to the GCC countries during the period 1980-2002, along Dunning's (1981) ownership-location-internalization (OLI) paradigm. 20 Estimates show that oil production, oil reserves, and oil prices have a

real GDP growth rate, (ii) inflation (proxied by the rate of change of the consumer price index), (iii) tax rate (measured by the corporate profit tax rate), and (iv) external debt (measured by total external debt as a percentage of GDP). He adopts a panel data fixed effects model to control for country and time effects.

17 The dependent variable is the ratio of FDI to GDP, while the explanatory variables are (a) the lagged dependent variable, (b) the lagged real GDP growth, (c) the ratio of exports and imports to GDP as a proxy of trade openness, and (d) the weighted average bond yield in the G7 countries to account for external push factors. He uses a dynamic panel model of FDI flows and system GMM estimation methodology.

18 Creditworthiness variables are the ratios of long-term debt to GDP, total debt to GDP, and the difference between total debt and international reserves to GDP.

19 The dependent variable in this model is the stock of inward FDI in the host MENA country, while the explanatory variables include (a) real GDP, (b) size of population, (c) exports relative to GDP, (d) imports relative to GDP, and (e) telephone mainlines. Variables are expressed in log form. Real GDP and population size are proxies for purchasing power and market size, respectively. Exports and imports reflect trade potential and are broken down by region into MENA, European Union, and rest of the world. Telephone mainlines are used to proxy for infrastructure. The 18 countries included in the sample are Algeria, Bahrain, Egypt, Iran, Israel, Jordan, Kuwait, Lebanon, Morocco, Oman, Qatar, Saudi Arabia, Sudan, Syria, Tunisia, Turkey, United Arab Emirates, and Yemen. They estimate a spatial error autocorrelation model with both fixed spatial and time effects, and also accounting for third country characteristics (impact of characteristics of nearby countries on FDI in host country) using a maximum likelihood estimation technique.

20 The dependent variable is net FDI inflows relative to GDP, while the explanatory variables are: (a) oil resources, (b) oil price, (c) market size measured by real GDP , (d) human capital proxied by secondary school enrollment relative to total school enrollment, (e) trade openness measured by the sum of merchandise exports and imports relative to GDP, (f) infrastructure development measured by the sum of telephone mainlines and cellular mobile phones per 1,000 people, and $(\mathrm{g})$ institutional quality proxied by the rule of law indicator. Oil resources are measured using three 
surprisingly negative influence on FDI flows, contrary to expectations about positive association between oil resources and FDI. However, when expressing oil production relative to oil reserves, the influence becomes positive. Estimates also show that while institutional quality, trade openness, and infrastructure development have encouraged FDI flows, human capital has significantly discouraged them.

The findings of the MENA FDI determinants literature reveal two main points. First, for GCC countries natural resources and human capital discourage FDI flows, while institutional quality, trade openness, and infrastructure development encourage them. Second, more generally in MENA countries from market fundamentals perspective market potential encourage FDI, while evidence on economic growth is inconclusive. From institutions perspective, the level and stability of institutional quality positively influence FDI. Accordingly, what is common among these studies is that trade and institutional quality encourage FDI in the MENA region, a point we keep in mind in this research.

\section{MENA domestic institutional function and investment treaties experience}

\subsection{Domestic institutional function performance}

In assessing the performance of domestic institutional functions, we compare the PRP and political functions performance of the sample MENA countries to that of (24) OECD countries using International Country Risk Guide's (ICRG) political risk components. 21 The period under investigation is 1990-2008 in which BITs contracted by MENA countries proliferated. Table 1 shows the MENA countries average performance with respect to the risk of investment expropriation (labelled 'investment profile') and law and order is not far away from OECD average performance, contrary to common perceptions. Average MENA countries performance on risk of investment expropriation amounted to about 87 per cent while law and order amounted to 77 per cent. The performance on corruption and bureaucracy quality was poor, however, reaching about 55 and 52 per cent of OECD average, respectively.

Within the MENA countries, the GCC countries scored higher than non-GCC countries. The average performance of GCC countries on investment expropriation risk, law and order, and bureaucracy quality was nearly 20 per cent higher than that for non-GCC countries, but about 13 per cent lower on corruption.

As far as political institutional functions are concerned, the average performance fared better than PRP average. Government stability was better in the MENA region than in the OECD countries and outperformed it by 12 per cent. Performance on ethnic tensions, external, and internal conflict amounted to 93 per cent, 90 per cent, and 86 per cent, respectively. The worst performance, however, was on democratic accountability accounting for about 40 per cent of OECD average. Within the MENA

different approaches: (a) reserves, (b) production, and (c) oil production relative to reserves. All variables are in log forms. He uses fixed/random effects panel data models.

21 A higher score indicates a lower risk. More information on the political risk components is provided in section 4 below. 
region, the GCC countries performed on average better than non-GCC countries except for democratic accountability.

Individual country performance is provided in Table 2. Oman had the highest average score on investment expropriation risk, Jordan on corruption and democratic accountability, Bahrain on law and order, and on bureaucracy quality with the UAE, Morocco and Syria on government stability, Qatar on ethnic tensions, Tunisia on internal conflicts and religion in politics, Algeria on external conflicts, and the UAE on bureaucracy quality together with Bahrain on military in politics.

What these statistics suggest is that based on investment expropriation risk alone there might not be enough justification for MENA countries to sign BITs, however. There are other institutional functions, both PRP and political, that may have been associated with contracting BITs and therefore should be considered when assessing institutional reforms.

\subsection{BITs entered into force}

The MENA countries have entered into force 300 treaties in total, as Table 3 shows, one third of which are with high-income OECD countries. 22 Egypt entered into force the largest number of treaties (64), followed by Morocco (35), and Kuwait (33). Excluding Libya which has been embargoed internationally until the first half of the 2000s, Saudi Arabia accounted for the least number of treaties. Morocco ratified the largest number of treaties with OECD countries (13) followed by Egypt (12), and Tunisia (11).

\subsection{Association between FDI inflows, domestic institutional functions, and BITs}

Table 4 shows average FDI flows to MENA countries in the period 1985-2008. Among the non-GCC countries, Egypt attracted the highest level on average amounting to US\$2.3 billion, while Syria attracted the least (US\$0.3 billion). Among the GCC countries, Saudi Arabia and the UAE attracted the highest levels amounting on average to US\$4 billion and US\$3 billion, respectively, followed by Qatar, Bahrain, Oman, and Kuwait.

The correlation between FDI inflows, domestic PRP institutional functions, and BITs for all MENA countries and for the GCC and non-GCC countries separately is provided in Table 5. FDI inflows are mostly correlated with investment expropriation risk on the PRP side and government stability on the political side. An improvement in expropriation risk is positively associated with FDI inflows to the MENA countries.

Among the different income classifications of BITs, FDI inflows are mostly associated with those entered into force with high-income OECD countries in the sample countries. However, the country breakdown shows that this association is significant only in the non-GCC countries. In addition OECD treaties have mostly been associated with investment expropriation risk and government stability in non-

22 The income classification of BITs is discussed in Section 5 below. 
GCC countries and government stability and investment expropriation risk in GCC countries, as Table 6 shows.

\section{Empirical model and hypotheses}

\subsection{Empirical model}

Gravity models have been increasingly used in empirical studies to explore bilateral FDI flows, such as Bellack et al. (2008), Bevan and Estrin (2004), Desbordes and Vicard (2009), Frenkel et al. (2004), Hallward-Driemeier (2003), and Wei (2000). However, in the absence of bilateral FDI flows data on MENA countries, adoption of a typical gravity model becomes infeasible.

We should note, however, that gravity models in essence constitute an extension of the location advantage hypothesis of Dunning's (1981) OLI paradigm. The location advantage hypothesis argues that for a multinational corporation to invest abroad location advantages have to exist in the host market. These advantages include natural and human resource endowments, market size, level of economic development, degree of openness of the economy, conducive economic policies, and PRP.

Of the many location advantages that characterize the MENA region, natural and human resource endowments stand out. In the MENA region, natural resource endowments include both oil $(\mathrm{O})$ and natural gas reserves $(\mathrm{G})$, which attract resourceseeking FDI. Resource-rich MENA countries in the sample include Algeria $(\mathrm{O} / \mathrm{G})$, Egypt $(\mathrm{G})$, Kuwait $(\mathrm{O} / \mathrm{G})$, Libya $(\mathrm{O} / \mathrm{G})$, Qatar $(\mathrm{O} / \mathrm{G})$, Saudi Arabia $(\mathrm{O})$, and UAE $(\mathrm{O} / \mathrm{G}) .23$ Table 7 shows oil and natural gas reserves in the MENA region. Some MENA countries are labour abundant, such as Algeria, Egypt, Jordan, Morocco, Tunisia, and Syria.

The empirical model expresses FDI flows as:

$$
\begin{aligned}
& \ln \left(\text { FDIFLOWS }_{\mathrm{it}}\right)=\beta_{0}+\beta_{1} \ln \left(\text { FDIFLOWS }_{\mathrm{it}-1}\right)+\beta_{2} \ln \left(\text { INSTITFN }_{\mathrm{it}}\right)+\beta_{3} \text { BIT }_{\mathrm{it}} \\
& +\beta_{4} \text { BITINSTITFN }_{\mathrm{it}}+\beta_{5} \ln \left(\text { OIL }_{\mathrm{it}}\right)+\beta_{6} \ln \left(\text { PRICE }_{\mathrm{it}}\right)+\beta_{7} \ln \left(\text { LABOUR }_{\mathrm{it}}\right) \\
& +\beta_{8} \ln \left(\text { TRADE }_{\mathrm{it}}\right)+\beta_{9} \ln \left(\text { INFLATION }_{\mathrm{it}}\right)+\beta_{10} \ln \left(\text { WFDIFLOWS }_{\mathrm{it}}\right)+\varepsilon_{\mathrm{it}}
\end{aligned}
$$

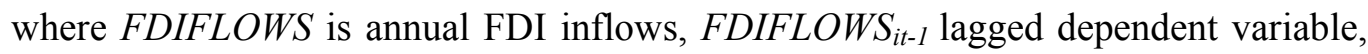
INSTITFN domestic PRP institutional function, BIT bilateral investment treaty entered into force, BITINSTITFN is an interaction term between the natural logarithm of domestic PRP institutional function on the one hand and BITs on the other,24 OIL oil production, PRICE oil price, LABOUR labour force, TRADE trade, INFLATION

23 Libya and Qatar are later dropped from the sample due to missing observations, as discussed in the section.

24 This term is introduced to model policy interaction between domestic institutional functions and BITs. It is constructed as $\ln \left(I N S T I T F N_{i t}\right) * B I T_{i t}$. 
inflation rate, WFDIFLOWS world FDI flows, and $\varepsilon$ an error term. 25 The subscripts $i$ and $t$ are country and time indicators with $i=1, \ldots, N$ and $t=1, \ldots, T$. In the panel dataset used, $N=11$ and $T=17$ for the period 1991-2007. Appendix A provides more information on variables.

We use annual FDI flows rather than FDI stocks to examine PRP influence, through domestic institutional functions and BITs, on changes in FDI stock. Also we use the level of FDI flows as opposed to the ratio of FDI flows to GDP in order to capture the change in FDI stocks directly and not their relative weight to the host country. $26 \mathrm{We}$ normalize FDI flows by population size to account for differences in size of economies as a robustness exercise, as discussed in Section 8.

The inclusion of a lagged dependent variable in the empirical model serves two purposes. First, it accounts for the persistence in FDI flows, especially when these flows are related to natural resources. Natural resources require flows of foreign investment over time. Second, it mitigates the likely upward bias in the influence of BITs and domestic PRP institutional functions on FDI flows. This bias likely results from the lack of bilateral FDI data and the consequent modelling of BITs as BITs as further discussed in the next section. We expect the variable coefficient to be positive.

$B I T$ is the total (cumulative) number of BITs entered into force. We use BITs entered into force as opposed to signed treaties to account for actual commitment to PRP by contracting MENA countries. Treaties are expected to reduce political risk and strengthen PRP, and encourage FDI inflows. Therefore the coefficient of BIT is expected to be positive.

INSTITFN is domestic PRP institutional function. Because PRP is a multidimensional process, we model PRP using four ICRG political risk components: investment profile, corruption, law and order, and bureaucracy quality. These four functions are outcomes of the legal and judicial systems and government bureaucracy, and are essential to PRP. Investment profile refers to the risk of investment expropriation, profits repatriation, and payment delays, clearly influencing PRP. Corruption is a threat to PRP as it enables people to assume positions of power through patronage rather than ability, constituting a threat to the rights of foreign investors as they facilitate government expropriation of investment or when direct conflicts with those patrons arise. Law and order refers to the strength and impartiality of the legal system as well as the popular observance of the law. Quality of bureaucracy refers to bureaucracy governing without drastic changes in policy when governments change. Higher scores on these political risk indices indicate better performance. A positive coefficient for each of these functions is expected.

25 We should note that because of a high correlation coefficient between oil production and domestic market size, as measured by nominal and real GDP, of about 0.9 for the sample countries we decided to omit the latter. For GCC and non-GCC countries this coefficient is about 0.9 and 0.5 , respectively.

26 This is similar to Hallward-Driemeier (2003) and Neumayer and Spess (2005). 
In addition to the four PRP institutional functions, we also add government stability, a political institutional function, based on the correlation between FDI, the different domestic institutional coefficients, and BITs of Tables 4 and 5. Government stability refers to the ability of the government to carry out its declared programme(s) and stay in office. A positive coefficient of government stability is also expected.

BITINSTITFN is an interaction term between domestic institutional functions and BITs. This term is included to allow for the interplay between domestic PRP institutional functions and BITs. A positive coefficient indicates that institutional functions and treaties complement each other, while a negative coefficient indicates if they are rather substitutes.

OIL and PRICE are oil production and prices, respectively. ${ }^{27}$ Because oil production requires capital and technology, we expect the OIL coefficient to be positive. Similarly higher oil prices encourage the supply of oil, up to a limit in OPEC countries at least, and thus we expect a positive PRICE coefficient similarly.

LABOUR is included to account for human resource endowments in MENA countries. Some measure of labour productivity or unit labour cost would be ideal if we need to reflect the wage differentials between home and host countries. 28 Alternatively some measure of education, such as the share of secondary school enrolment in total school enrolment, would be ideal to account for human capital. However data on labour productivity measures and on secondary school enrolment are largely missing. ${ }^{29} \mathrm{We}$ would expect a positive $L A B O U R$ coefficient.

$T R A D E$ is a measure of the degree of openness of the economy. An open economy is conducive for FDI flows, and therefore we expect a positive coefficient. INFLATION is a proxy for macroeconomic stability in the economy. A higher inflation rate is an indicator of lower macroeconomic stability and real incomes, and therefore discourages FDI flows. A negative coefficient is expected.

WFDIFLOWS is included to take into account the business cycle in the global economy. MENA countries are likely to obtain more FDI flows with expansion of the world economy and global FDI flows. A positive coefficient is expected.

\subsection{Testable hypotheses}

We use the above empirical model provided by equation (1) to test whether the second best approach to PRP institutional reform, as opposed to the first best approach, has a positive influence on FDI flows to the MENA countries. As mentioned in the introduction, the first best comprises domestic institutional functions

27 See footnote 26 on the correlation between oil production and domestic market size.

28 Bellak et al. (2008) in examining the influence of labour costs on FDI flows to Central and Eastern European countries use unit labour costs and labour productivity.

29 World Development Indicators data on secondary school enrollment are unavailable from 2002 or 2003 onwards for the sample countries. 
only, whereas the second best comprises both domestic institutional functions and BITs.

First hypothesis: domestic PRP institutional functions have a positive influence of FDI flows to MENA countries.

$$
\begin{aligned}
& \mathrm{H}_{0}: \beta_{2}=0 \\
& \mathrm{H}_{1}: \beta_{2}>0
\end{aligned}
$$

Second hypothesis: domestic PRP institutional functions and BITs have a positive influence of FDI flows to MENA countries.

$$
\begin{aligned}
& \mathrm{H}_{0}: \beta_{2}=0 ; \beta_{3}=0 \\
& \mathrm{H}_{1}: \beta_{2}>0 ; \beta_{3}>0
\end{aligned}
$$

\section{Data and empirical issues and estimation methodology}

\subsection{Data issues}

FDI data on MENA countries are obtained from UNCTAD's FDI online database. Because of the fluctuation of FDI flows as reflected in the standard deviation and the range of values shown in Table 8, we use natural logarithm. To get around zeros and negative value, we use the same approach adopted by Blonigen and Davies (2004) and Neumayer and Spess (2005). 30 If the value of FDI flows is zero, we add one dollar and take the natural logarithm, resulting in a value of zero; otherwise we would have obtained no value as the log of zero does not exist. If the value of FDI flows is negative, we take the negative of the natural logarithm of the absolute value of FDI flows. The same approach is used with INSTITFN and OIL.

Data on BITs are also obtained from UNCTAD's FDI online database. We classified contracting partner countries for each of the 11 MENA countries into high-income OECD, high-income non-OECD, upper middle-income, lower middle-income, and low-income countries. In this categorization we follow the World Bank 2005 classification, instead of the most recent 2009 classification, to extend consistently earlier empirical work by the author.

The sample period was planned initially to be 1985-2008 and to cover 13 MENA countries: Algeria, Egypt, Jordan, Morocco, Syria, and Tunisia, in addition to the six oil-rich GCC countries: Bahrain, Kuwait, Oman, Saudi Arabia and the UAE.31 However due to missing observations on trade openness, defined as the sum of exports and imports as a percentage of GDP, for Libya and Qatar, these two countries

30 See Kerner (2009).

31 Lebanon is excluded from the sample due to the civil war and political unrest, which have plagued the country until recently, and the absence of natural resources, an important explanatory variable in the empirical model. 
were excluded.32 Also observations on trade openness for 2008 are missing for Bahrain, Libya, Oman, Qatar, and the UAE. Thus the sample period has been shortened to 1991-2007.33

\subsection{Empirical issues and estimation methodology}

The lack of bilateral data on FDI flows has constituted an empirical challenge for this study. Unlike previous studies which adopt gravity models and use bilateral FDI flows, this study uses FDI flows at the aggregate level. This limitation has affected the consequent modelling approach of the BITs entered into force and likely results in an upward coefficient bias of BIT (entered into force as opposed to signed), if there are positive FDI flows from contracting partner (home) countries with which there are no treaties entered into force. 34

The adopted modelling approach implies that BITs are de facto assumed to be equal in PRP strength. While this assumption can be argued against, it is not totally unrealistic from a legal perspective given the tendency to adopt 'standardized' clauses in many treaties. In addition there is not much variation in PRP strength among countries with similar income levels, and therefore we do not expect to have treaties with remarkable differences in the degree of PRP to be achieved.

In estimating the empirical model, there are a number of empirical issues that we need to consider. These are heterogeneity, endogeneity, and autocorrelation. We will discuss each issue in turn.

\subsubsection{Heterogeneity}

The performance of MENA countries with respect to FDI inflows, domestic institutional functions, and BITs is heterogeneous, as discussed in Section 3, and therefore is likely to generate heteroskedasticity in the error term. Thus we split the sample into GCC and non-GCC countries, and conducted a likelihood ratio (LR) test for heterogeneity. The p-values of the LR test for all model specifications were significant at the 1 per cent level indicating a failure to accept the null hypothesis of homoskedastic error term. 35 Therefore we decided first to adopt a feasible generalized least squares estimation (FGLS) approach. Appendix B provides the LR test statistics for the full sample and the two sub-samples for the different model specifications.

32 Missing observations on trade openness for Libya are for the periods 1985-90 and 2004-08. For Qatar, missing observations are for the period 1985-94 and in 2008.

33 Observations on labour force for Kuwait are missing for the period 1993-95 and have been interpolated. We applied compounded annual growth rates obtained for the period 1992-96 to the missing period.

34 This, however, would underestimate the influence of signed treaties, as Neumayer and Spess (2005) argue.

35 By different model specifications, we mean the empirical model with different domestic institutional functions. 


\subsubsection{Endogeneity}

Endogeneity in the model results from simultaneity and variable omission associated with unobservable country effects. Simultaneity arises from the reverse causality between FDI inflows on the one hand and BITs entered into force and domestic institutional functions on the other. 36 While BITs entered into force may influence FDI inflows, FDI inflows may also encourage FDI home country governments to contract investment treaties to protect the property rights of their investors abroad. Simultaneity also arises from the reverse causality between FDI inflows and the different domestic institutional functions, especially when foreign investors are major multinational corporations, such as those operating in mining and petro-chemicals and financial and telecommunications services in the MENA region.

Variable omission can be associated with unobservable country-specific effects, such as the degree of strength of foreign relationships a GCC country has with the rest of the world, including countries with which BITs are contracted. It can also be associated with omitted variables related to ownership advantages that foreign corporations have. This in turn results in correlation between the explanatory variables and the error term and in biased OLS estimates.

To overcome the endogeneity issue, we use lagged explanatory variables, similar to Neumayer and Spess (2005) and Tobin and Rose-Ackerman (2006). Adopting an instrumental variables estimation methodology and dynamic panel regression are other approaches to the endogeneity problem. However with the dearth of data on MENA countries, the selection of instruments becomes a very difficult and an ad hoc exercise.

\subsubsection{Autocorrelation}

For autocorrelation, we conducted the Wooldridge test for autocorrelation in the idiosyncratic errors of a linear panel data model, as suggested by Wooldridge (2002). 37 The null hypothesis of no serial correlation was rejected only at the 1 per cent significance level for the full sample and at the 5 per cent levels for the subsamples suggesting the presence of autocorrelation. Appendix B provides the test statistics for the full sample and the two sub-samples for the different model specifications. Accordingly we account for autocorrelation, both across and within panels, in regressions.

\section{Empirical results}

The iterative FGLS estimates for non-GCC and GCC countries sub-samples (with and without the interaction term BITINSTITFN) are provided in Tables 9A and 9B, respectively. Estimates are provided after accounting for heteroskedasticity and

36 See Mina (2009) on the potential endogeneity between FDI, domestic institutions and BITs in the GCC countries.

37 Under the null hypothesis of no serial correlation the residuals from the regression of the firstdifferenced variables should have an autocorrelation of -0.5 , implying that the coefficient on the lagged residuals in a regression of the lagged residuals on the current residuals should be -0.5 . 
within- and cross-panel correlations. Each column corresponds to an institutional function.

\subsection{Empirical results with no model interaction term}

The influence of BITs is positive and statistically significant at the 1 per cent level in all specifications for GCC countries and statistically insignificant in nearly all specifications for non-GCC countries, in Tables 9A-1 and 9B-1. For example, in column 1 of Table 9B-1, BIT coefficient suggests that for a GCC country a treaty entered into force with an OECD country increases FDI flows on average by 29.6 per cent (holding other explanatory variables constant).

Domestic institutional functions do not have a statistically significant influence in both sub-samples in almost all specifications. Only in GCC countries, the influence of investment expropriation risk is positive, but marginally significant.

The lagged dependent variable is positive and statistically significant in all specifications for all three tables suggesting persistence in FDI flows to MENA countries. However, it should be noted that the magnitude of persistence is much higher in GCC than in non-GCC countries. In the first specification of Table 9B-1 for example, an increase in FDI flows to GCC countries in the previous year by 1 per cent increases FDI flows in the current year by about 0.4 per cent compared to about 0.25 per cent in non-GCC countries.

Location factors are important determinants of FDI flows to MENA countries. In GCC countries oil prices and labour force attract FDI flows, while oil production and inflation discourage them. Trade openness on the other hand has a positive though statistically insignificant influence. In non-GCC countries labour force and trade openness play a positive and statistically significant role in attracting FDI flows. Similar to GCC countries, oil production has a negative, but marginally significant influence, while oil price has no statistically significant influence unlike GCC countries.

What is common to both GCC and non-GCC countries is the positive influence that labour force exerts on FDI flows. However, it should be noted that the magnitude of labour force influence is 60 per cent to 100 per cent higher in GCC countries than in non-GCC countries.

The association between world business cycle and FDI flows differ in the two country groups. FDI seems to flow pro-cyclically to non-GCC countries, i.e. with the world business cycle, but counter-cyclically to GCC countries. FDI outflows from GCC countries during world business cycle can be one possible interpretation for this result.

\subsection{Empirical results with model interaction term}

Including interaction term into the regressions has not changed the estimated influence of human and natural resource endowments, trade openness, macroeconomic stability, and world business cycle. However, the estimated influence has changed slightly for domestic institutional functions and BITs. Results show that 
in GCC countries the statistical significance of BIT coefficient drops from 1 per cent level in all specifications to at least 5 per cent level in only two specifications containing corruption and government stability (Table 9B-2). In the specification containing corruption, the coefficient of the interaction term is statistically significant at the 1 per cent level and is negative. This suggests that entry into force of a BIT reduces FDI flows when the country has less corruption. Therefore, less corruption and BITs tend to be substitutes in GCC countries. The same applies for government stability.

In non-GCC countries, the inclusion of the interaction term has changed the influence of domestic institutional function and BITs. Of the five model specifications, the specifications containing investment profile or risk of investment expropriation and government stability are worth discussing. The magnitude and statistical significance of INSTITFN in the investment profile specification has increased significantly, while its sign in the government stability specification has turned positive and statistically significant at the 1 per cent level. An improvement in investment expropriation risk and in government stability by 1 per cent increases FDI flows by about 1.5 per cent and 3 per cent, respectively. Also BIT coefficient has turned positive, and its magnitude and statistical significance increased to the 1 per cent level. The coefficient of BITINSTITFN is negative, suggesting that FDI flows less to countries with better risk of investment expropriation and government stability, suggesting these BITs and these two functions are substitutes in the non-GCC MENA countries.

\subsection{Hypothesis testing}

With the above results in place, we can now turn to discuss hypothesis testing, as specified in Section 4.2. For the first hypothesis of no influence of domestic institutional functions, it is clear that we fail to reject the null hypothesis in most model specifications, whether we include an interaction term or not, and for both GCC and non-GCC countries. In the case of non-GCC countries, the risk of investment expropriation has a positive influence on FDI flows, whether we include an interaction term or not, suggesting the importance of this institutional function for attracting FDI flows.

Examining the influence of BITs alone, which is the main component for conceptualizing the second best, the influence is different in GCC and non-GCC countries. In non-GCC countries, such influence is hardly significant both in economic and statistical size. In the only specification where it is statistically significant, an increase in the number of treaties by 1 increases FDI flows by about 0.4 per cent. In GCC countries, BIT coefficient is significant economically and statistically and suggests that its influence on FDI flows is about 30 per cent.

For the second hypothesis of no influence of domestic institutional functions and BITs, as well as the interaction between them, we can see from Tables 9A-2 and 9B-2 that the joint influence is positive in specifications containing investment expropriation risk and government stability in the case of non-GCC countries, and corruption in the case of GCC countries. 


\section{Robustness checks}

As mentioned in the empirical model sub-section (4.1), we normalize FDI flows by population size to account for differences in economy size. Results are reported in Tables 9C and 9D for non-GCC and GCC countries, respectively.

For non-GCC countries, as Tables 9C-1 and 9C-2 show, the coefficients of the lagged dependent variable are statistically significant in almost all specifications and of comparable magnitude to those in Tables 9A-1 and 9A-2. In Table 9C-2, the coefficients of domestic institutional functions, BITs, and the interaction term are significant in specifications 1 and 5 including risk of investment expropriation and government stability, similar to those in Table 9A-2. LABOUR coefficients drop to less than half of those in Table 9A-2 but still positive and statistically significant at the 1 per cent level.

For GCC countries, as Tables 9D-1 and 9D-2 show, the coefficients of the lagged dependent variable are statistically significant in all specifications and of comparable magnitude to those in Tables 9B-1 and 9B-2. The coefficients of other explanatory variables are also similar in magnitude and statistical significance. As in the case for non-GCC countries, LABOUR coefficients for GCC countries drop but not as much.

\section{Concluding remarks}

This research has explored the issue of how MENA countries can approach institutional reforms aiming at attracting FDI flows to the region. Should MENA countries in strengthening PRP focus on reforming domestic institutional functions alone-a first best approach-or should they reform domestic institutional functions together and contracting BITs at the same time?

This paper helps us draw a number of conclusions. First, conceptually the paper helps us conceive a second best approach to PRP institutional reforms. A second best approach to institutional reform should consider not only domestic institutional functions and BITs, but also the interaction between them. Second, from a policymaking perspective, policy makers ought not to think of MENA countries as one group of homogenous countries. Not only do MENA countries have different endowments, but they also differ in their institutional functions performance. Also evidence reveals that in non-GCC MENA countries improvement in the risk of investment expropriation and government stability are particularly influential domestic institutional functions for FDI flows, while in GCC countries corruption matters. Third, natural and human resource endowments matter to FDI flows to MENA countries.

Finally in answering the title question of whether there is one best that fits all MENA countries, the evidence seems to give a nod. Second best fits all MENA countries, but we need to be specific about the relevant domestic institutional functions in order to attract more FDI to either group of countries. 


\section{Appendix A}

Variables, definitions, and data sources

Variable

FDIFLOWS

BIT

INSTITFN

PRICE

LABOUR

TRADE

INFLATION

WFDIFLOWS
Definition

FDI flows in millions of USUS\$ (log)

Total number of BITs entered into force.

Domestic PRP institutional functions.

These are (a) investment profile, (b)

corruption, c) law and order, and (d)

bureaucracy quality (log).

Interaction term between BIT and

INSTITFN constructed as the product of

INSTITFN (log form) and BIT.

Oil production in thousands of barrels per day (log).

Crude oil price measured by the price of Saudi Arabian Light 34 in USUS\$/barrel

(log).

Labour force (log).

Sum of exports and imports as a

percentage of GDP (log).

Inflation rate in percentage $(\log )$. Rate is

calculated based on the consumer price

index, except for Oman and UAE where it

is based on GDP deflator.

World FDI inflows in millions of USUS\$ (in log form).
Source

UNCTAD's FDI online database.

Author's calculation based on UNCTAD's

BITs online database.

ICRG political risk index.

Author's calculation.

Energy Information Administration

Energy Information Administration

World Bank's World Development Indicators.

World Bank's World Development Indicators.

World Bank's World Development Indicators.

Author's calculation based on UNCTAD's BITs online database. 


\section{Appendix B}

Heterogeneity and serial correlation test statistics

\begin{tabular}{|c|c|c|c|}
\hline \multirow[t]{3}{*}{ INSTITFN } & Full & GCC & Non-GCC \\
\hline & Sample & Countries & Countries \\
\hline & \multicolumn{3}{|c|}{ Heterogeneity } \\
\hline Investment profile & 182.87 & 51.74 & 105.01 \\
\hline Corruption & 180.06 & 50.86 & 103.94 \\
\hline Law and order & 174.78 & 48.42 & 100.5 \\
\hline Bureaucracy quality & 178.19 & 50.39 & 98.85 \\
\hline \multirow[t]{2}{*}{ Government stability } & 176.03 & 50.5 & 94.55 \\
\hline & \multicolumn{3}{|c|}{ Serial correlation } \\
\hline Investment profile & 17.13 & 11.919 & $24.89^{*}$ \\
\hline Corruption & 19.16 & 11.757 & 8.59 \\
\hline Law and order & 19.41 & 13.282 & 9.13 \\
\hline Bureaucracy quality & 19.38 & 15.32 & 8.11 \\
\hline Government stability & 19.61 & 12.946 & 8.26 \\
\hline
\end{tabular}

Notes: Heterogeneity likelihood ratio (chi-squared) test statistics are significant at the $1 \%$ level. Serial correlation $(F)$ test statistics are significant at the $1 \%$ level for the full sample, and $5 \%$ level for the subsamples; an asterisk indicates significance at the $1 \%$ level for the sub-samples. 


\section{References}

Alfaro, L., Kalemli-Ozcan, S., and Volosovych, V. (2008). 'Why Doesn't Capital Flow from Rich to Poor Countries? An Empirical Investigation'. Review of Economics and Statistics, 90 (2): 347-68.

Asiedu, E. (2006). 'Foreign Direct Investment in Africa: The Role of Natural Resources, Market Size, Government Policy, Institutions and Political Instability'. World Economy, 29 (1): 63-77.

Bellack, C., Leibrecht, M., and Riedl, A. (2008). 'Labour Costs and FDI flows into Central and Eastern European Countries: A Survey of the Literature and Empirical Evidence'. Structural Change and Economic Dynamics, 19 (1): 17-37.

Bevan, A. A., and Estrin, S. (2004). 'The Determinants of Foreign Direct Investment into European Transition Economies'. Journal of Comparative Economics, 32 (4): $775-87$.

Blonigen, B. A., and Davies, R. B. (2004). 'The Effects of Bilateral Tax Treaties on US FDI Activity'. International Tax and Public Finance, 11 (5): 601-22.

Bowerman, B. L., O’Connell, R., and Koehler, A. (2005). Forecasting, Time Series, and Regression. California: Thomson Brooks/Cole.

Busse, M., and Hefeker, C. (2007). 'Political Risk, Institutions and Foreign Direct Investment'. European Journal of Political Economy, 23 (2): 397-415.

Chan, K. K., and Gemayel, E. R. (2004). 'Risk Instability and the Pattern of Foreign Direct Investment in the Middle East and North Africa Region'. Working Paper WP/04/139. Washington, DC: IMF.

Daude, C., and Fratzscher, M. (2008). 'The Pecking Order of Cross-Border Investment'. Journal of International Economics, 74 (1): 94-119.

Daude, C., and Stein, E. (2007). 'The Quality of Institutions and Foreign Direct Investment'. Economics and Politics, 19 (3): 317-44.

Desbordes, R., and Vicard, V. (2009). 'Foreign Direct Investment and Bilateral Investment Treaties: An International Political Perspective'. Journal of Comparative Economics, 37 (3): 372-86.

Dixit, A. (2009). 'Governance Institutions and Economic Activity'. American Economic Review, 99 (1): 5-24.

Du, J., Lu, Y., and Tao, Z. (2008). 'Economic Institutions and FDI Location Choice: Evidence from US Multinationals in China'. Journal of Comparative Economics, 36 (3): 412-29.

Dunning, J. (1981). International Production and the Multinational Enterprise. London: Allen \& Unwin.

Elkins, Z., Guzman A. T., and Simmons, B. A. (2006). 'Competing for Capital: The Diffusion of Bilateral Investment Treaties, 1960-2000.' International Organization, 60 (4): 811-46. 
Egger, P., and Pfaffermayr, M. (2004). 'The Impact of Bilateral Investment Treaties on Foreign Direct Investment'. Journal of Comparative Economics, 32 (4): 788804.

Egger, P., and Merlo, V. (2007). 'The Impact of Bilateral Investment Treaties on FDI Dynamics'. World Economy, 30 (10): 1536-49.

Faria, A., and Mauro, P. (2009). 'Institutions and the External Capital Structure of Countries'. Journal of International Money and Finance, 28 (3): 367-91.

Frenkel, M., Funke K., and Stadtmann G. (2004). 'A Panel Analysis of Bilateral FDI Flows to Emerging Economies’. Economic Systems, 28 (3): 281-300.

Hallward-Driemeier, M. (2003). 'Do Bilateral Investment Treaties Attract FDI? Only a Bit... and They Could Bite'. Policy Research Working Paper 3121. Washington, DC: World Bank.

Henisz, W. J. (2000). 'The Institutional Environment for Economic Growth'. Economics and Politics, 12 (1): 1-31.

Hisarciklilar, M., Kayalica, S. S., and Kayalica, O. (2007). 'Locational Drivers of FDI in MENA Countries: A Spatial Attempt'. MPRA Paper 2085. Munich: Munich Personal RePEc Archive.

Kamaly, A. (2002). 'Evaluation of FDI flows into the MENA Region'. Mimeo. Cairo: American University, Department of Economics.

Kandil, M., and Mirzaie, I. (2009). 'The Impact of Capital and Remittances Flows on Economic Performance in MENA Countries'. World Economics, 10 (3): 159-92.

Kerner, A. (2009). 'Why Should I Believe You? The Costs and Consequences of Bilateral Investment Treaties'. International Studies Quarterly, 53 (1): 73-102.

Korgstup, S., and Matter, L. (2005). 'Foreign Direct Investment, Absorptive Capacity and Growth in the Arab World'. Working Paper 02/2005. Geneva: Graduate Institute of International Studies.

Kraay, A., and Nehru, V. (2006). 'When is External Debt Sustainable?'. World Bank Economic Review, 20 (3): 341-65.

Lane, P. R. (2004). 'Empirical Perspectives on Long-Term External Debt'. Topics in Macroeconomics'. 4 (1): 1-21.

Mina, W. (2009). 'External Commitment Mechanisms, Institutions, and FDI in GCC Countries'. Journal of International Financial Markets, Institutions, \& Money, 19 (2): 371-86.

Mina, W. (2006). 'Does Contract Enforcement Matter for International Lending?'. Applied Economics Letters, 13 (6): 359-64.

Mina, W., and Martinez-Vazquez, J. (2006). 'Contract Enforcement, Institutional Stability and the Level and Maturity of International Lending'. International Studies Program Working Paper 06-17. Atlanta: Andrew Young School of Policy Studies. 
Mishra, A., and Daly, K. (2007). 'Effect of Quality of Institutions on Outward Foreign Direct Investment'. Journal of International Trade and Economic Development, 16 (2): 231-44.

Naudé, W. A., and Krugell, W. F. (2007). 'Investigating Geography and Institutions as Determinants of Foreign Direct Investment in Africa Using Panel Data'. Applied Economics, 39 (10-12): 1223-33.

Neumayer, E., and Spess, L. (2005). 'Do Bilateral Investment Treaties Increase Foreign Direct Investment to Developing Countries?'. World Development, 33 (10): 1567-85.

North, D. C. (1991). 'Institutions'. Journal of Economic Perspectives, 5 (1): 97-112.

Omran, M., and Bolbol, A. (2003). 'Foreign Direct Investment, Financial Development, and Economic Growth: Evidence from the Arab Countries'. Review of Middle East Economics and Finance, 1 (3): 231-49.

Onyeiwu, S. (2003). 'Analysis of FDI Flows to Developing Countries: Is the MENA Region Different?'. Paper presented at ERF's 10th Annual Conference, Marrakech, Morocco.

Rodrik, D. (2008). 'Second-best Institutions'. American Economic Review: Papers \& Proceedings, 98 (2): 100-4.

Sadik, A. T., and Bolbol, A. A. (2001). 'Capital Flows, FDI, and Technology Spillovers: Evidence from Arab Countries'. World Development, 29 (12): 211125.

Tobin, J., and Rose-Ackerman, S. (2006). 'When BITs have Similar Bite: The Political Economic Environment for Bilateral Investment Treaties'. Mimeo. Yale University, Law School.

UNCTAD (1998). Bilateral Investment Treaties in the Mid-1990s. Geneva. United Nations.

Wei, S.-J. (2000). 'How Taxing is Corruption on International Investors?'. Review of Economics and Statistics, 82 (1): 1-11.

Wooldridge, J. M. (2002). Introductory Econometrics: A Modern Approach. Ohio: Thomson South Western. 
Table 1: Domestic institutional functions in MENA and OECD countries (1990-2008)

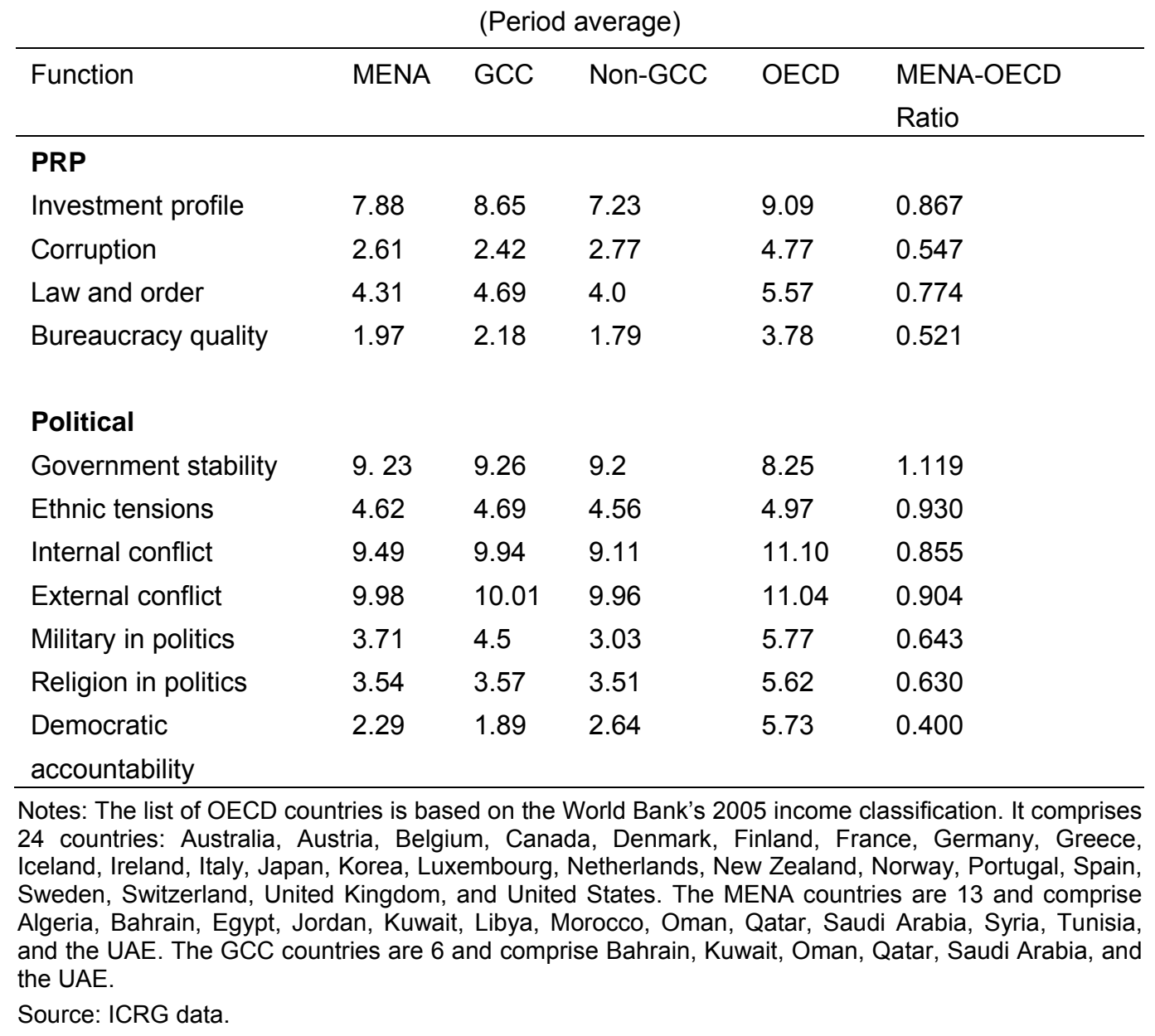


Table 2: Period averages for MENA countries (1985-2008)

\begin{tabular}{|c|c|c|c|c|c|c|c|c|c|c|c|c|}
\hline Country & FDI & IP & $\mathrm{C}$ & L\&O & $B Q$ & GS & ET & IC & $\mathrm{EC}$ & MP & $\mathrm{RP}$ & DA \\
\hline Algeria & 540.5 & 6.9 & 2.7 & 2.3 & 1.7 & 8.3 & 3.2 & 6.4 & 10.2 & 1.3 & 2 & 3 \\
\hline Egypt & $2,296.10$ & 6.3 & 2.2 & 3.4 & 2 & 8.5 & 4.9 & 7.9 & 9.6 & 2.7 & 2.4 & 3.1 \\
\hline Jordan & 513.5 & 7.2 & 3.3 & 3.6 & 2.1 & 8.6 & 4.4 & 8.6 & 9.3 & 4.3 & 3.1 & 3.6 \\
\hline Libya & 516 & 6.9 & 3 & 3.4 & 1.2 & 8.1 & 4.1 & 8.7 & 8.5 & 2.4 & 3.7 & 1.5 \\
\hline Morocc & 921.7 & 7.3 & 2.9 & 4.4 & 2.1 & 9.1 & 4.4 & 8.6 & 9.2 & 3.6 & 3.7 & 3 \\
\hline \multicolumn{13}{|l|}{ o } \\
\hline Syria & 291.8 & 5.4 & 2.7 & 4 & 1.2 & 9.1 & 4.8 & 9.7 & 7.9 & 1.9 & 4.2 & 1.5 \\
\hline Tunisia & 686.5 & 7.2 & 2.7 & 4 & 2 & 8.8 & 5 & 9.9 & 9.7 & 3.8 & 4.4 & 2.5 \\
\hline Total & 823.7 & 6.7 & 2.8 & 3.6 & 1.8 & 8.6 & 4.4 & 8.6 & 9.2 & 2.9 & 3.3 & 2.6 \\
\hline Bahrain & 611.4 & 8.1 & 2.9 & 4.8 & 2.5 & 8.3 & 3.9 & 8.3 & 9.9 & 3.9 & 3.6 & 2.2 \\
\hline Kuwait & 37.6 & 8 & 2.7 & 4.3 & 1.9 & 8 & 4.1 & 8.9 & 8.6 & 4.6 & 2.7 & 2.6 \\
\hline Oman & 461.7 & 8.5 & 2.8 & 4.5 & 2.2 & 9 & 4.6 & 9.8 & 9.9 & 4 & 4.1 & 1.8 \\
\hline Qatar & 915.8 & 8 & 2.1 & 4.6 & 1.7 & 8.7 & 5.3 & 9.6 & 8.7 & 4.1 & 3.7 & 1.9 \\
\hline Saudi & $4,108.50$ & 8.2 & 2.1 & 4.6 & 2.3 & 8.5 & 4.5 & 9 & 9 & 4.5 & 2.6 & 1 \\
\hline \multicolumn{13}{|l|}{ Arabia } \\
\hline UAE & $2,863.20$ & 8.3 & 2.3 & 3.7 & 2.5 & 8.3 & 3.6 & 9.4 & 9.3 & 4.7 & 3.4 & 2 \\
\hline Total & $1,499.70$ & 8.2 & 2.5 & 4.4 & 2.2 & 8.5 & 4.3 & 9.1 & 9.2 & 4.3 & 3.4 & 1.9 \\
\hline
\end{tabular}

Notes: FDI (FDI inflows in USUS\$ million), IP (investment profile), C (corruption), L\&O (law and order), BQ (bureaucratic quality), GS (government stability), ET (ethnic tensions), IC (internal conflict), EC (external conflict), MP (military in politics), RP (religion in politics), and DA (democratic accountability).

Source: Author's calculations based on UNCTAD and ICRG data. 
Table 3: Total BITs entered into force (June 2008)

(by income level of contracting partner)

\begin{tabular}{lllllll}
\hline & All & $\begin{array}{l}\text { High- } \\
\text { Income } \\
\text { OECD }\end{array}$ & $\begin{array}{l}\text { High- } \\
\text { Income } \\
\text { Non- } \\
\text { OECD }\end{array}$ & $\begin{array}{l}\text { Upper } \\
\text { Middle- } \\
\text { Income }\end{array}$ & $\begin{array}{l}\text { Lower } \\
\text { Middle- } \\
\text { Income }\end{array}$ & $\begin{array}{l}\text { Low- } \\
\text { Income }\end{array}$ \\
\hline MENA & 300 & 100 & 18 & 45 & 104 & 32 \\
Algeria & 15 & 6 & 1 & 2 & 4 & 2 \\
Egypt & 64 & 12 & 7 & 12 & 21 & 12 \\
Jordan & 28 & 10 & 1 & 6 & 9 & 2 \\
Libya & 8 & 3 & 0 & 0 & 5 & 0 \\
Morocco & 35 & 13 & 4 & 7 & 10 & 1 \\
Syria & 20 & 5 & 3 & 2 & 8 & 2 \\
Tunisia & 25 & 11 & 1 & 5 & 7 & 1 \\
Total & 195 & 60 & 17 & 34 & 64 & 20 \\
GCC & & & & & & \\
Bahrain & 10 & 2 & 0 & 0 & 7 & 0 \\
Kuwait & 33 & 10 & 1 & 7 & 10 & 5 \\
Oman & 19 & 9 & 0 & 0 & 6 & 4 \\
Qatar & 11 & 5 & 0 & 0 & 5 & 1 \\
Saudi Arabia & 8 & 5 & 0 & 0 & 3 & 0 \\
UAE & 24 & 9 & 0 & 4 & 9 & 2 \\
Total & 105 & 40 & 1 & 11 & 40 & 12 \\
\hline Tas: & & & & & & \\
\end{tabular}

Notes: Using World Bank's 2005 income classification of countries.

Source: UNCTAD (1998). 
Table 4: FDI flows in MENA countries (1985-2008)

(Period average in US\$ million)

\begin{tabular}{ll}
\hline Country/region & Value \\
\hline Non-GCC countries & \\
Algeria & 540.51 \\
Egypt & $2,296.09$ \\
Jordan & 513.47 \\
Libya & 515.96 \\
Morocco & 921.68 \\
Syria & 291.81 \\
Tunisia & 686.49 \\
Total & $\mathbf{8 2 3 . 7 1 5}$ \\
& \\
GCC countries & \\
Bahrain & 611.36 \\
Kuwait & 37.59 \\
Oman & 461.66 \\
Qatar & 915.77 \\
Saudi Arabia & $4,108.54$ \\
UAE & $2,863.19$ \\
Total & $\mathbf{1 , 4 9 9 . 6 9}$ \\
MENA total & $\mathbf{1 , 1 3 5 . 7 0}$ \\
\hline T &
\end{tabular}

Source: UNCTAD (1998). 
Table 5: Correlation between FDI inflows, institutional functions,

\begin{tabular}{llll}
\multicolumn{4}{c}{ and BITs (1990-2008) } \\
\hline & All & $\begin{array}{l}\text { Non- } \\
\text { GCC }\end{array}$ & GCC \\
\hline PRP & & & \\
Investment profile & $0.373 \mathrm{~b}$ & $0.498 \mathrm{~b}$ & $0.392 \mathrm{~b}$ \\
Corruption & -0.260 & $-0.383 \mathrm{~b}$ & $-0.212 \mathrm{~b}$ \\
Law and order & $0.149 \mathrm{~b}$ & $0.267 \mathrm{~b}$ & 0.170 \\
Bureaucratic quality & 0.080 & $0.240 \mathrm{~b}$ & 0.059 \\
& & & \\
Political & & & \\
Government stability & $0.426 \mathrm{~b}$ & $0.562 \mathrm{~b}$ & $0.325 \mathrm{~b}$ \\
Ethnic tensions & $0.216 \mathrm{~b}$ & 0.124 & $0.320 \mathrm{~b}$ \\
Internal conflict & 0.125 & $0.233 \mathrm{~b}$ & 0.092 \\
External conflict & 0.082 & -0.008 & 0.168 \\
Military in religion & 0.124 & $0.410 \mathrm{~b}$ & -0.054 \\
Religion in politics & $0.197 \mathrm{~b}$ & $0.255 \mathrm{~b}$ & $0.236 \mathrm{~b}$ \\
Democratic accountability & -0.118 & -0.088 & $-0.238 \mathrm{~b}$ \\
& & & \\
BITs & & & \\
All & & & \\
OECD & $0.313 \mathrm{~b}$ & $0.504 \mathrm{~b}$ & 0.039 \\
High-income non-OECD & $0.337 \mathrm{~b}$ & $0.544 \mathrm{~b}$ & 0.113 \\
Upper middle-income & $0.243 \mathrm{~b}$ & $0.386 \mathrm{~b}$ & $-0.225 \mathrm{~b}$ \\
Lower middle-income & $0.238 \mathrm{~b}$ & $0.489 \mathrm{~b}$ & -0.149 \\
Low-income & $0.267 \mathrm{~b}$ & $0.411 \mathrm{~b}$ & 0.077 \\
\hline Wh the exceton of BIs, vatabs & $0.183 \mathrm{~b}$ & $0.348 \mathrm{~b}$ & -0.082 \\
\hline
\end{tabular}

Notes: With the exception of BITs, variables are in log forms. b significant at $5 \%$ level. Sample excludes Lebanon, Libya, and Qatar.

Source: Correlation coefficients obtained using STATA 9.0. 
Table 6: Correlation between institutional functions and BITs

\begin{tabular}{|c|c|c|c|c|c|}
\hline \multicolumn{6}{|c|}{ (1990-2008) } \\
\hline & IP & L\&O & $\mathrm{C}$ & $B Q$ & GS \\
\hline All & $0.323 b$ & $0.179 \mathrm{~b}$ & $-0.387 b$ & 0.021 & $0.419 b$ \\
\hline OECD & $0.456 b$ & $0.259 \mathrm{~b}$ & $-0.303 b$ & 0.124 & $0.496 \mathrm{~b}$ \\
\hline High-income non- & 0.044 & 0.093 & $-0.325 b$ & $-0.136 b$ & $0.240 \mathrm{~b}$ \\
\hline \multicolumn{6}{|l|}{ OECD } \\
\hline Upper middle-income & $0.234 b$ & $0.140 \mathrm{~b}$ & $-0.274 b$ & 0.056 & $0.329 b$ \\
\hline Lower middle-income & $0.337 \mathrm{~b}$ & $0.190 \mathrm{~b}$ & $-0.421 b$ & 0.002 & $0.425 b$ \\
\hline Low-income & $0.138 b$ & 0.024 & $-0.359 b$ & -0.054 & $0.248 b$ \\
\hline \multicolumn{6}{|l|}{ Non-GCC } \\
\hline All & $0.387 b$ & $0.292 b$ & $-0.513 b$ & 0.139 & $0.417 b$ \\
\hline OECD & $0.548 b$ & $0.401 b$ & $-0.425 b$ & $0.253 b$ & $0.463 b$ \\
\hline High-income non- & $0.198 b$ & $0.227 \mathrm{~b}$ & $-0.494 b$ & -0.002 & $0.324 b$ \\
\hline \multicolumn{6}{|l|}{ OECD } \\
\hline Upper middle-income & $0.423 b$ & $0.321 b$ & $-0.395 b$ & $0.202 b$ & $0.414 b$ \\
\hline Lower middle-income & $0.353 b$ & $0.268 b$ & $-0.486 b$ & 0.067 & $0.404 b$ \\
\hline Low-income & 0.133 & 0.050 & $-0.536 b$ & 0.069 & $0.236 b$ \\
\hline \multicolumn{6}{|l|}{ GCC } \\
\hline All & $0.502 \mathrm{~b}$ & 0.161 & $-0.208 b$ & 0.042 & $0.499 b$ \\
\hline OECD & $0.494 b$ & 0.151 & -0.149 & 0.098 & $0.555 b$ \\
\hline High-income non- & 0.030 & $0.245 b$ & 0.065 & -0.162 & 0.101 \\
\hline \multicolumn{6}{|l|}{ OECD } \\
\hline Upper middle-income & 0.202 & 0.009 & -0.178 & 0.140 & $0.216 \mathrm{~b}$ \\
\hline Lower middle-income & $0.517 b$ & 0.171 & $-0.359 b$ & 0.038 & $0.515 b$ \\
\hline Low-income & $0.339 \mathrm{~b}$ & 0.164 & 0.065 & -0.195 & $0.308 b$ \\
\hline
\end{tabular}

Notes: With the exception of BITs, variables are in log forms. b significant at $5 \%$ level. Sample excludes Lebanon, Libya, and Qatar.

Source: Correlation coefficients obtained using STATA 9.0. 
Table 7: Natural and human resource endowments in MENA region

\begin{tabular}{|c|c|c|c|c|c|}
\hline \multicolumn{4}{|c|}{ Natural resources } & \multicolumn{2}{|c|}{ Human resources } \\
\hline Oil & & Natural ga & & Populatio & \\
\hline Country & $\begin{array}{l}\text { Reserves } \\
\text { in } \\
\text { thousands } \\
\text { bpd } \\
(2009)\end{array}$ & Country & $\begin{array}{l}\text { Reserves in } \\
\text { billion cubic } \\
\text { feet } \\
(2008)\end{array}$ & Country & $\begin{array}{l}\text { Size in } \\
\text { million } \\
(2007)\end{array}$ \\
\hline Saudi Arabia & 266.7 & Qatar & 905.3 & Egypt & 75.5 \\
\hline Kuwait & 104.0 & UAE & 214.4 & Algeria & 33.9 \\
\hline UAE & 97.8 & Algeria & 159 & Morocco & 30.9 \\
\hline Libya & 43.7 & Egypt & 58.5 & $\begin{array}{l}\text { Saudi } \\
\text { Arabia }\end{array}$ & 24.2 \\
\hline Qatar & 15.2 & Kuwait & 56.0 & Syria & 19.9 \\
\hline Algeria & 12.2 & Libya & 50.1 & Tunisia & 10.2 \\
\hline Oman & 5.5 & Oman & 30.0 & Libya & 6.2 \\
\hline Egypt & 3.7 & Syria & 8.5 & Jordan & 5.7 \\
\hline Syria & 2.5 & Bahrain & 3.3 & UAE & 4.4 \\
\hline Tunisia & 0.4 & Tunisia & 2.3 & Kuwait & 2.7 \\
\hline Bahrain & 0.1 & Jordan & 0.2 & Oman & 2.6 \\
\hline Jordan & 0.0 & Morocco & 0.1 & Qatar & 0.8 \\
\hline Morocco & 0.0 & $\begin{array}{l}\text { Saudi } \\
\text { Arabia }\end{array}$ & 0.0 & Bahrain & 0.8 \\
\hline
\end{tabular}

Notes: Countries are listed by resource endowments rank. Oil and natural gas reserves data are obtained from the Energy Information Administration website. Population size data are obtained from the United Nations Common Database. 
Table 8: Descriptive statistics

\begin{tabular}{|c|c|c|c|c|c|}
\hline Variable & Obs & Mean & Std. Dev. & Min & Max \\
\hline FDIFLOWS & 187 & $1,246.82$ & $3,106.91$ & (985.34) & $24,318.40$ \\
\hline \multicolumn{6}{|l|}{ INSTITFN } \\
\hline Investment profile & 187 & 7.92 & 2.18 & 1.25 & 11.50 \\
\hline Corruption & 187 & 2.63 & 0.71 & 1.50 & 4.00 \\
\hline Law and order & 187 & 4.37 & 1.00 & 1.42 & 6.00 \\
\hline Bureaucracy quality & 187 & 2.03 & 0.48 & 0.58 & 3.00 \\
\hline Government stability & 187 & 9.34 & 1.55 & 4.25 & 11.21 \\
\hline $\mathrm{BIT}$ & 187 & 4.58 & 3.51 & - & 12.00 \\
\hline OIL & 187 & $1,641.28$ & $2,656.53$ & $(1.46)$ & $11,096.31$ \\
\hline PRICE & 187 & 24.02 & 12.13 & 10.03 & 55.94 \\
\hline LABOUR & 187 & $5,635,635.00$ & $6,177,569.00$ & $228,519.20$ & $25,800,000.00$ \\
\hline TRADE & 184 & 91.35 & 35.57 & 38.36 & 181.12 \\
\hline INFLATION & 187 & 4.38 & 6.35 & $(13.35)$ & 31.67 \\
\hline \multirow[t]{2}{*}{ WFDIFLOWS } & 187 & $726,345.70$ & $498,401.40$ & $155,685.60$ & $1,978,838.00$ \\
\hline & & \multicolumn{2}{|c|}{ Variables (log) } & & \\
\hline FDIFLOWS & 187 & 5.24 & 3.03 & $(6.89)$ & 10.10 \\
\hline \multicolumn{6}{|l|}{ INSTITFN } \\
\hline Investment profile & 187 & 2.03 & 0.31 & 0.22 & 2.44 \\
\hline Corruption & 187 & 0.93 & 0.27 & 0.41 & 1.39 \\
\hline Law and order & 187 & 1.44 & 0.28 & 0.35 & 1.79 \\
\hline Bureaucracy quality & 187 & 0.68 & 0.27 & $(0.54)$ & 1.10 \\
\hline Government stability & 187 & 2.22 & 0.19 & 1.45 & 2.42 \\
\hline OIL & 187 & 5.55 & 2.80 & $(2.79)$ & 9.31 \\
\hline PRICE & 187 & 3.08 & 0.44 & 2.31 & 4.02 \\
\hline LABOUR & 187 & 14.88 & 1.25 & 12.34 & 17.06 \\
\hline TRADE & 184 & 4.44 & 0.38 & 3.65 & 5.20 \\
\hline INFLATION & 187 & 1.01 & 1.25 & $(3.20)$ & 3.46 \\
\hline WFDIFLOWS & 187 & 13.24 & 0.74 & 11.96 & 14.50 \\
\hline
\end{tabular}

Source: Appendix A provides data sources for variables above. 
Table 9A-1: Institutional functions, BITs and FDI flows to non-GCC Countries Dependent variable: log of FDI inflows

\begin{tabular}{|c|c|c|c|c|c|}
\hline & $(1)$ & $(2)$ & (3) & $(4)$ & $(5)$ \\
\hline VARIABLES & IP & C & L\&O & $B Q$ & GS \\
\hline \multirow[t]{2}{*}{ FDIFLOWS(-1) } & $0.232 a$ & $0.270 a$ & $0.294 a$ & $0.171 b$ & 0.114 \\
\hline & $(0.081)$ & $(0.077)$ & $(0.077)$ & $(0.078)$ & $(0.088)$ \\
\hline \multirow[t]{2}{*}{ INSTITFN } & $0.534 c$ & 0.128 & 0.277 & -0.412 & -0.106 \\
\hline & $(0.306)$ & $(0.285)$ & $(0.267)$ & $(0.300)$ & $(0.416)$ \\
\hline \multirow[t]{2}{*}{ BIT } & -0.014 & -0.001 & 0.001 & -0.012 & $0.037 \mathrm{c}$ \\
\hline & $(0.017)$ & $(0.019)$ & $(0.018)$ & $(0.020)$ & $(0.020)$ \\
\hline \multirow[t]{2}{*}{ OIL } & -0.026 & $-0.053 c$ & -0.045 & -0.052 & $-0.079 a$ \\
\hline & $(0.030)$ & $(0.030)$ & $(0.032)$ & $(0.035)$ & $(0.030)$ \\
\hline \multirow[t]{2}{*}{ PRICE } & 0.201 & 0.144 & 0.145 & 0.164 & 0.191 \\
\hline & $(0.199)$ & $(0.215)$ & $(0.229)$ & $(0.212)$ & $(0.204)$ \\
\hline \multirow[t]{2}{*}{ LABOUR } & $1.591 a$ & $1.501 a$ & $1.495 a$ & $1.694 a$ & $1.399 a$ \\
\hline & $(0.178)$ & $(0.174)$ & $(0.177)$ & $(0.191)$ & (0.191) \\
\hline \multirow[t]{2}{*}{ TRADE } & $2.984 a$ & $2.681 \mathrm{a}$ & $2.819 a$ & $2.984 a$ & $2.180 \mathrm{a}$ \\
\hline & $(0.440)$ & $(0.438)$ & $(0.415)$ & $(0.442)$ & $(0.518)$ \\
\hline \multirow[t]{2}{*}{ INFLATION } & 0.073 & $0.159 c$ & $0.199 b$ & $0.163 b$ & 0.065 \\
\hline & $(0.082)$ & $(0.083)$ & $(0.080)$ & $(0.080)$ & $(0.090)$ \\
\hline \multirow[t]{2}{*}{ WFDIFLOWS } & 0.169 & $0.391 a$ & $0.382 b$ & $0.388 a$ & $0.409 a$ \\
\hline & $(0.138)$ & $(0.132)$ & $(0.153)$ & $(0.137)$ & $(0.155)$ \\
\hline \multirow[t]{2}{*}{ Constant } & $-36.495 a$ & $-36.001 a$ & $-36.901 a$ & $-39.249 a$ & $-31.399 a$ \\
\hline & $(4.327)$ & $(4.349)$ & $(4.495)$ & $(4.562)$ & $(4.603)$ \\
\hline Observations & 102 & 102 & 102 & 102 & 102 \\
\hline Number of groups & 6 & 6 & 6 & 6 & 6 \\
\hline
\end{tabular}

Notes: 'IP', 'C', 'L\&O', 'BQ', and 'GS' are investment profile, corruption, law and order, bureaucracy quality, and government stability respectively. a,b,c significant at $1 \%, 5 \%$, and $10 \%$ level, respectively. Standard errors in parentheses. Iterative FGLS used in estimation and heteroskedastic error structure with cross and within panel autocorrelation accounted for. 
Table 9A-2: Institutional functions, BITs and FDI flows to non-GCC Countries Dependent variable: log of FDI inflows -interaction term

\begin{tabular}{|c|c|c|c|c|c|}
\hline & (1) & $(2)$ & $(3)$ & $(4)$ & $(5)$ \\
\hline VARIABLES & IP & $\mathrm{C}$ & L\&O & $B Q$ & GS \\
\hline \multirow[t]{2}{*}{ FDIFLOWS(-1) } & $0.221 a$ & $0.196 b$ & $0.246 a$ & $0.133 c$ & $0.258 a$ \\
\hline & $(0.077)$ & $(0.079)$ & $(0.079)$ & $(0.079)$ & $(0.077)$ \\
\hline \multirow[t]{2}{*}{ INSTITFN } & $1.460 a$ & -0.209 & -0.094 & -0.571 & $3.115 \mathrm{a}$ \\
\hline & $(0.345)$ & $(0.329)$ & $(0.295)$ & $(0.386)$ & $(0.808)$ \\
\hline \multirow[t]{2}{*}{ BIT } & $0.401 a$ & $-0.074 b$ & -0.041 & -0.105 & $1.980 a$ \\
\hline & $(0.105)$ & $(0.035)$ & $(0.124)$ & $(0.128)$ & $(0.456)$ \\
\hline \multirow[t]{2}{*}{ BITINSTITFN } & $-0.207 a$ & $0.104 b$ & 0.033 & 0.148 & $-0.846 a$ \\
\hline & $(0.054)$ & $(0.046)$ & $(0.088)$ & $(0.170)$ & $(0.197)$ \\
\hline \multirow[t]{2}{*}{ OIL } & $-0.048 c$ & -0.010 & -0.049 & -0.054 & $-0.085 a$ \\
\hline & $(0.028)$ & $(0.032)$ & $(0.033)$ & $(0.034)$ & $(0.031)$ \\
\hline \multirow[t]{2}{*}{ PRICE } & $0.352 c$ & 0.091 & 0.139 & 0.218 & 0.185 \\
\hline & $(0.196)$ & $(0.215)$ & $(0.215)$ & $(0.210)$ & $(0.239)$ \\
\hline \multirow[t]{2}{*}{ LABOUR } & $1.513 a$ & $1.716 a$ & $1.444 a$ & $1.597 a$ & $1.303 a$ \\
\hline & $(0.167)$ & $(0.177)$ & $(0.186)$ & $(0.187)$ & $(0.164)$ \\
\hline \multirow[t]{2}{*}{ TRADE } & $2.849 a$ & $3.211 \mathrm{a}$ & $2.592 \mathrm{a}$ & $2.690 a$ & $2.266 a$ \\
\hline & $(0.409)$ & $(0.452)$ & $(0.461)$ & $(0.453)$ & $(0.456)$ \\
\hline \multirow[t]{2}{*}{ INFLATION } & 0.075 & 0.099 & 0.134 & $0.156 c$ & $0.221 a$ \\
\hline & $(0.081)$ & $(0.081)$ & $(0.084)$ & $(0.082)$ & $(0.080)$ \\
\hline \multirow[t]{2}{*}{ WFDIFLOWS } & $0.257 c$ & $0.303 b$ & $0.340 \mathrm{~b}$ & $0.377 a$ & $0.478 a$ \\
\hline & $(0.132)$ & $(0.143)$ & $(0.158)$ & $(0.140)$ & $(0.165)$ \\
\hline \multirow[t]{2}{*}{ Constant } & $-37.932 a$ & $-39.716 a$ & $-33.659 a$ & $-36.145 a$ & $-39.453 a$ \\
\hline & $(4.251)$ & $(4.232)$ & $(4.760)$ & $(4.400)$ & $(4.348)$ \\
\hline Observations & 102 & 102 & 102 & 102 & 102 \\
\hline Number of groups & 6 & 6 & 6 & 6 & 6 \\
\hline $\mathrm{HO}: \beta_{2}=0$ & $17.93 a$ & - & - & - & $14.87 a$ \\
\hline $\mathrm{HO}: \beta_{2}=0 ; \beta_{3}=0$ & $20.32 a$ & - & - & - & $18.82 \mathrm{a}$ \\
\hline $\mathrm{HO}: \beta_{2}=0 ; \beta_{3}=0 ; \beta_{4}=0$ & $20.59 a$ & - & - & - & $20.03 a$ \\
\hline
\end{tabular}

Notes: 'IP', 'C', 'L\&O', 'BQ', and 'GS' are investment profile, corruption, law and order, bureaucracy quality, and government stability respectively. a,b,c significant at $1 \%, 5 \%, 10 \%$ level, respectively. Standard errors in parentheses. Iterative FGLS used in estimation and heteroskedastic error structure with cross and within panel autocorrelation accounted for. 
Table 9B-1: Institutional functions, BITs and FDI flows to GCC countries Dependent variable: log of FDI inflows

\begin{tabular}{|c|c|c|c|c|c|}
\hline & (1) & $(2)$ & (3) & $(4)$ & (5) \\
\hline VARIABLES & IP & C & L\&O & $B Q$ & GS \\
\hline \multirow[t]{2}{*}{ FDIFLOWS(-1) } & $0.366 a$ & $0.409 a$ & $0.401 a$ & $0.387 a$ & $0.378 a$ \\
\hline & $(0.085)$ & $(0.081)$ & $(0.084)$ & $(0.080)$ & $(0.079)$ \\
\hline \multirow[t]{2}{*}{ INSTITFN } & 0.507 & 0.224 & 0.087 & -0.100 & -0.591 \\
\hline & $(0.658)$ & $(1.781)$ & $(0.912)$ & $(0.713)$ & $(0.969)$ \\
\hline \multirow[t]{2}{*}{ BIT } & $0.296 a$ & $0.298 a$ & $0.316 a$ & $0.291 \mathrm{a}$ & $0.295 a$ \\
\hline & (0.091) & $(0.080)$ & $(0.081)$ & $(0.081)$ & $(0.083)$ \\
\hline \multirow[t]{2}{*}{ OIL } & $-1.603 a$ & $-1.623 a$ & $-1.542 a$ & $-1.694 a$ & $-1.767 a$ \\
\hline & $(0.524)$ & $(0.524)$ & $(0.517)$ & $(0.513)$ & $(0.513)$ \\
\hline \multirow[t]{2}{*}{ PRICE } & $1.143 b$ & $1.356 a$ & $1.236 \mathrm{a}$ & $1.429 a$ & $1.505 a$ \\
\hline & $(0.445)$ & $(0.441)$ & $(0.442)$ & $(0.436)$ & $(0.422)$ \\
\hline \multirow[t]{2}{*}{ LABOUR } & $2.695 a$ & $2.728 a$ & $2.613 a$ & $2.759 a$ & $2.828 a$ \\
\hline & $(0.733)$ & $(0.858)$ & $(0.721)$ & $(0.695)$ & (0.695) \\
\hline \multirow[t]{2}{*}{ TRADE } & -0.143 & -0.448 & -0.178 & -0.566 & -0.726 \\
\hline & $(0.956)$ & $(0.916)$ & $(0.925)$ & $(0.952)$ & $(0.946)$ \\
\hline \multirow[t]{2}{*}{ INFLATION } & $-0.133 c$ & $-0.174 b$ & $-0.169 b$ & $-0.174 b$ & $-0.186 b$ \\
\hline & $(0.078)$ & $(0.074)$ & $(0.074)$ & $(0.074)$ & $(0.075)$ \\
\hline \multirow[t]{2}{*}{ WFDIFLOWS } & $-0.735 b$ & $-0.712 b$ & $-0.710 b$ & $-0.731 b$ & $-0.652 c$ \\
\hline & $(0.317)$ & $(0.297)$ & $(0.337)$ & $(0.320)$ & $(0.334)$ \\
\hline \multirow[t]{2}{*}{ Constant } & $-18.377 a$ & $-17.687 c$ & $-17.446 a$ & $-16.624 a$ & $-16.345 a$ \\
\hline & $(6.065)$ & $(10.328)$ & $(6.295)$ & $(6.101)$ & $(5.672)$ \\
\hline Observations & 85 & 85 & 85 & 85 & 85 \\
\hline Number of groups & 5 & 5 & 5 & 5 & 5 \\
\hline
\end{tabular}

Notes: 'IP', 'C', 'L\&O', 'BQ', and 'GS' are investment profile, corruption, law and order, bureaucracy quality, and government stability respectively. a,b,c significant at $1 \%, 5 \%$, and $10 \%$ level, respectively. Standard errors in parentheses. Iterative FGLS used in estimation and heteroskedastic error structure with cross and within panel autocorrelation accounted for. 
Table 9B-2: Institutional functions, BITs and FDI flows to GCC countries Dependent variable: log of FDI Inflows-interaction term

\begin{tabular}{|c|c|c|c|c|c|}
\hline & (1) & (2) & (3) & (4) & (5) \\
\hline VARIABLES & IP & $C$ & L\&O & $B Q$ & GS \\
\hline \multirow[t]{2}{*}{ FDIFLOWS(-1) } & $0.353 a$ & $0.301 a$ & $0.350 a$ & $0.353 a$ & $0.326 a$ \\
\hline & $(0.085)$ & $(0.084)$ & $(0.085)$ & $(0.081)$ & $(0.082)$ \\
\hline \multirow[t]{2}{*}{ INSTITFN } & -0.092 & $3.676 \mathrm{c}$ & 0.836 & -0.773 & 0.966 \\
\hline & $(0.829)$ & (2.053) & $(1.012)$ & $(1.037)$ & $(0.985)$ \\
\hline \multirow[t]{2}{*}{ BIT } & -0.017 & $1.086 a$ & $2.278 \mathrm{c}$ & 0.064 & $1.499 b$ \\
\hline & $(0.492)$ & $(0.286)$ & $(1.228)$ & $(0.256)$ & $(0.743)$ \\
\hline \multirow[t]{2}{*}{ BITINSTITFN } & 0.154 & $-0.903 a$ & -1.240 & 0.283 & $-0.523 c$ \\
\hline & $(0.216)$ & $(0.288)$ & $(0.756)$ & $(0.331)$ & $(0.317)$ \\
\hline \multirow[t]{2}{*}{ OIL } & $-1.537 a$ & $-1.540 a$ & $-1.787 a$ & $-1.803 a$ & $-1.544 a$ \\
\hline & $(0.526)$ & $(0.551)$ & $(0.524)$ & $(0.518)$ & $(0.504)$ \\
\hline \multirow[t]{2}{*}{ PRICE } & $1.077 \mathrm{~b}$ & $1.382 a$ & $1.609 a$ & $1.664 a$ & $1.351 \mathrm{a}$ \\
\hline & $(0.424)$ & $(0.442)$ & $(0.458)$ & $(0.444)$ & $(0.419)$ \\
\hline \multirow[t]{2}{*}{ LABOUR } & $2.597 a$ & $2.666 a$ & $2.845 a$ & $2.856 a$ & $2.553 a$ \\
\hline & $(0.755)$ & $(0.884)$ & $(0.724)$ & $(0.704)$ & $(0.707)$ \\
\hline \multirow[t]{2}{*}{ TRADE } & 0.000 & -1.157 & -0.949 & -0.830 & -0.222 \\
\hline & $(0.980)$ & $(0.918)$ & $(0.919)$ & $(0.950)$ & $(0.947)$ \\
\hline \multirow[t]{2}{*}{ INFLATION } & $-0.137 c$ & -0.022 & $-0.144 b$ & $-0.177 b$ & $-0.132 c$ \\
\hline & $(0.078)$ & $(0.068)$ & $(0.069)$ & $(0.072)$ & $(0.068)$ \\
\hline \multirow[t]{2}{*}{ WFDIFLOWS } & $-0.711 b$ & $-0.655 b$ & $-0.741 b$ & $-0.760 b$ & $-0.646 c$ \\
\hline & $(0.316)$ & $(0.314)$ & $(0.363)$ & $(0.341)$ & $(0.345)$ \\
\hline \multirow[t]{2}{*}{ Constant } & $-16.993 b$ & $-17.515 c$ & $-17.156 a$ & $-15.616 a$ & $-19.153 a$ \\
\hline & $(6.825)$ & $(10.312)$ & $(5.823)$ & $(6.028)$ & $(6.446)$ \\
\hline Observations & 85 & 85 & 85 & 85 & 85 \\
\hline Number of groups & 5 & 5 & 5 & 5 & 5 \\
\hline $\mathrm{H} 0: \beta_{2}=0$ & - & - & - & - & $3.2 \mathrm{a}$ \\
\hline $\mathrm{HO}: \beta_{2}=0 ; \beta_{3}=0$ & - & - & - & - & $14.41 \mathrm{a}$ \\
\hline $\mathrm{HO}: \beta_{2}=0 ; \beta_{3}=0 ; \beta_{4}=0$ & - & - & - & - & $17.89 a$ \\
\hline
\end{tabular}

Notes: 'IP', 'C', 'L\&O', 'BQ', and 'GS' are investment profile, corruption, law and order, bureaucracy quality, and government stability respectively. a,b,c significant at $1 \%, 5 \%$, and $10 \%$ level, respectively. Standard errors in parentheses. Iterative FGLS used in estimation and heteroskedastic error structure with cross and within panel autocorrelation accounted for. 
Table 9C-1: Institutional functions, BITs and FDI flows to non-GCC countries Dependent variable: log of FDI inflows per capita

\begin{tabular}{|c|c|c|c|c|c|}
\hline & (1) & $(2)$ & (3) & (4) & (5) \\
\hline VARIABLES & IP & $\mathrm{C}$ & L\&O & $B Q$ & GS \\
\hline \multirow[t]{2}{*}{ FDIFLOWSCAPITA(-1) } & $0.258 a$ & $0.312 a$ & $0.331 a$ & $0.194 b$ & $0.149 c$ \\
\hline & -0.082 & -0.079 & -0.08 & -0.08 & -0.087 \\
\hline \multirow[t]{2}{*}{ INSTITFN } & $0.571 b$ & 0.1 & 0.128 & -0.122 & -0.019 \\
\hline & -0.29 & -0.284 & -0.252 & -0.312 & -0.402 \\
\hline \multirow[t]{2}{*}{ BIT } & -0.005 & 0.009 & 0.012 & 0.004 & $0.031 c$ \\
\hline & -0.016 & -0.018 & -0.017 & -0.019 & -0.019 \\
\hline \multirow[t]{2}{*}{ OIL } & -0.033 & $-0.061 b$ & $-0.058 b$ & $-0.054 c$ & $-0.091 a$ \\
\hline & -0.026 & -0.026 & -0.029 & -0.031 & -0.027 \\
\hline \multirow[t]{2}{*}{ PRICE } & 0.206 & 0.141 & 0.134 & 0.206 & 0.24 \\
\hline & -0.187 & -0.204 & -0.218 & -0.198 & -0.195 \\
\hline \multirow[t]{2}{*}{ LABOUR } & $0.773 a$ & $0.715 a$ & $0.711 \mathrm{a}$ & $0.681 a$ & $0.548 a$ \\
\hline & -0.129 & -0.129 & -0.131 & -0.154 & -0.152 \\
\hline \multirow[t]{2}{*}{ TRADE } & $2.831 \mathrm{a}$ & $2.522 \mathrm{a}$ & $2.599 a$ & $2.644 a$ & $2.130 \mathrm{a}$ \\
\hline & -0.443 & -0.441 & -0.426 & -0.461 & -0.499 \\
\hline \multirow[t]{2}{*}{ INFLATION } & 0.049 & 0.137 & $0.167 b$ & $0.154 c$ & 0.056 \\
\hline & -0.082 & -0.084 & -0.082 & -0.085 & -0.088 \\
\hline \multirow[t]{2}{*}{ WFDIFLOWS } & 0.127 & $0.355 a$ & $0.339 b$ & $0.354 a$ & $0.344 b$ \\
\hline & -0.131 & -0.127 & -0.147 & -0.129 & -0.143 \\
\hline \multirow[t]{2}{*}{ Constant } & $-24.901 a$ & $-24.783 a$ & $-25.030 a$ & $-24.319 a$ & $-19.986 a$ \\
\hline & -3.765 & -3.823 & -3.953 & -4.169 & -4.078 \\
\hline Observations & 102 & 102 & 102 & 102 & 102 \\
\hline Number of groups & 6 & 6 & 6 & 6 & 6 \\
\hline
\end{tabular}

Notes: 'IP', 'C', 'L\&O', 'BQ', and 'GS' are investment profile, corruption, law and order, bureaucracy quality, and government stability respectively. a,b,c significant at $1 \%, 5 \%$, and $10 \%$ level, respectively. Standard errors in parentheses. Iterative FGLS used in estimation and heteroskedastic error structure with cross and within panel autocorrelation accounted for. 
Table 9C-2: Institutional functions, BITs and FDI flows to non-GCC countries Dependent variable: log of FDI inflows per capita-interaction term

\begin{tabular}{|c|c|c|c|c|c|}
\hline & $(1)$ & $(2)$ & (3) & $(4)$ & $(5)$ \\
\hline VARIABLES & IP & $\mathrm{C}$ & L\&O & $B Q$ & GS \\
\hline \multirow[t]{2}{*}{ FDIFLOWSCAPITA(-1) } & $0.290 a$ & $0.237 a$ & $0.299 a$ & 0.111 & $0.276 a$ \\
\hline & -0.074 & -0.082 & -0.08 & -0.078 & -0.078 \\
\hline \multirow[t]{2}{*}{ INSTITFN } & $1.566 a$ & -0.215 & -0.061 & -0.442 & $3.327 a$ \\
\hline & -0.327 & -0.332 & -0.276 & -0.41 & -0.81 \\
\hline \multirow[t]{2}{*}{ BIT } & $0.439 a$ & $-0.058 c$ & -0.008 & -0.223 & $1.977 \mathrm{a}$ \\
\hline & -0.097 & -0.035 & -0.116 & -0.141 & -0.44 \\
\hline \multirow[t]{2}{*}{ BITINSTITFN } & $-0.221 a$ & $0.090 b$ & 0.015 & $0.323 c$ & $-0.844 a$ \\
\hline & -0.05 & -0.044 & -0.082 & -0.191 & -0.19 \\
\hline \multirow[t]{2}{*}{ OIL } & $-0.060 b$ & -0.028 & $-0.058 b$ & -0.045 & $-0.092 a$ \\
\hline & -0.025 & -0.027 & -0.029 & -0.029 & -0.028 \\
\hline \multirow[t]{2}{*}{ PRICE } & $0.308 \mathrm{c}$ & 0.112 & 0.138 & $0.360 \mathrm{c}$ & 0.255 \\
\hline & -0.187 & -0.205 & -0.208 & -0.189 & -0.229 \\
\hline \multirow[t]{2}{*}{ LABOUR } & $0.688 a$ & $0.851 a$ & $0.656 a$ & $0.438 a$ & $0.527 a$ \\
\hline & -0.115 & -0.129 & -0.139 & -0.147 & -0.132 \\
\hline \multirow[t]{2}{*}{ TRADE } & $2.766 a$ & $2.977 a$ & $2.475 a$ & $2.165 a$ & $2.028 a$ \\
\hline & -0.392 & -0.456 & -0.45 & -0.445 & -0.443 \\
\hline \multirow[t]{2}{*}{ INFLATION } & 0.066 & 0.091 & 0.128 & $0.147 c$ & $0.233 a$ \\
\hline & -0.08 & -0.081 & -0.084 & -0.084 & -0.082 \\
\hline \multirow[t]{2}{*}{ WFDIFLOWS } & 0.209 & $0.277 b$ & $0.319 b$ & $0.380 a$ & $0.418 a$ \\
\hline & -0.127 & -0.132 & -0.148 & -0.125 & -0.154 \\
\hline \multirow[t]{2}{*}{ Constant } & $-26.600 a$ & $-27.329 a$ & $-22.961 a$ & $-18.703 a$ & $-28.436 a$ \\
\hline & -3.548 & -3.747 & -4.179 & -3.869 & -3.981 \\
\hline Observations & 102 & 102 & 102 & 102 & 102 \\
\hline Number of groups & 6 & 6 & 6 & 6 & 6 \\
\hline $\mathrm{HO}: \beta_{2}=0$ & $22.97 a$ & - & - & - & $16.89 a$ \\
\hline $\mathrm{HO}: \beta_{2}=0 ; \beta_{3}=0$ & $26.65 a$ & - & - & - & $20.38 a$ \\
\hline $\mathrm{HO}: \beta_{2}=0 ; \beta_{3}=0 ; \beta_{4}=0$ & $27.76 a$ & - & - & - & $21.57 a$ \\
\hline
\end{tabular}

Notes: 'IP', 'C', 'L\&O', 'BQ', and 'GS' are investment profile, corruption, law and order, bureaucracy quality, and government stability respectively. a,b,c significant at $1 \%, 5 \%$, and $10 \%$ level, respectively. Standard errors in parentheses. Iterative FGLS used in estimation and heteroskedastic error structure with cross and within panel autocorrelation accounted for. 
Table 9D-1: Institutional functions, BITs and FDI flows to GCC countries Dependent variable: log of FDI inflows per capita

\begin{tabular}{|c|c|c|c|c|c|}
\hline & $(1)$ & $(2)$ & (3) & (4) & $(5)$ \\
\hline VARIABLES & IP & $\mathrm{C}$ & L\&O & $B Q$ & GS \\
\hline \multirow[t]{2}{*}{ FDIFLOWSCAPITA(-1) } & $0.326 a$ & $0.373 a$ & $0.358 a$ & $0.362 a$ & $0.352 a$ \\
\hline & $(0.086)$ & $(0.083)$ & $(0.087)$ & $(0.082)$ & $(0.082)$ \\
\hline \multirow[t]{2}{*}{ INSTITFN } & 0.636 & 0.030 & 0.221 & 0.014 & -0.478 \\
\hline & $(0.665)$ & $(1.816)$ & $(0.918)$ & $(0.766)$ & $(0.973)$ \\
\hline \multirow[t]{2}{*}{ BIT } & $0.301 a$ & $0.320 a$ & $0.331 a$ & $0.305 a$ & $0.314 a$ \\
\hline & $(0.095)$ & $(0.082)$ & $(0.083)$ & $(0.083)$ & $(0.085)$ \\
\hline \multirow[t]{2}{*}{ OIL } & $-1.572 a$ & $-1.580 a$ & $-1.556 a$ & $-1.637 a$ & $-1.700 a$ \\
\hline & $(0.517)$ & $(0.520)$ & $(0.511)$ & $(0.512)$ & $(0.516)$ \\
\hline \multirow[t]{2}{*}{ PRICE } & $0.958 b$ & $1.103 a$ & $1.069 b$ & $1.184 a$ & $1.231 \mathrm{a}$ \\
\hline & $(0.438)$ & $(0.424)$ & $(0.434)$ & $(0.423)$ & $(0.413)$ \\
\hline \multirow[t]{2}{*}{ LABOUR } & $2.112 a$ & $2.151 b$ & $2.128 a$ & $2.187 a$ & $2.243 a$ \\
\hline & $(0.714)$ & $(0.835)$ & $(0.697)$ & $(0.682)$ & $(0.688)$ \\
\hline \multirow[t]{2}{*}{ TRADE } & 0.550 & 0.292 & 0.465 & 0.165 & 0.067 \\
\hline & $(0.967)$ & $(0.975)$ & $(0.961)$ & $(0.974)$ & $(0.975)$ \\
\hline \multirow[t]{2}{*}{ INFLATION } & -0.115 & $-0.158 b$ & $-0.152 b$ & $-0.156 b$ & $-0.168 b$ \\
\hline & $(0.081)$ & $(0.077)$ & $(0.077)$ & $(0.077)$ & $(0.079)$ \\
\hline \multirow[t]{2}{*}{ WFDIFLOWS } & $-0.685 b$ & $-0.658 b$ & $-0.675 b$ & $-0.668 b$ & $-0.618 c$ \\
\hline & $(0.317)$ & $(0.293)$ & $(0.333)$ & $(0.311)$ & $(0.326)$ \\
\hline \multirow[t]{2}{*}{ Constant } & $-14.601 b$ & -13.690 & $-14.263 b$ & $-13.224 b$ & $-12.819 b$ \\
\hline & $(6.408)$ & (10.581) & $(6.647)$ & $(6.479)$ & $(6.121)$ \\
\hline Observations & 85 & 85 & 85 & 85 & 85 \\
\hline Number of groups & 5 & 5 & 5 & 5 & 5 \\
\hline
\end{tabular}

Notes: 'IP', 'C', 'L\&O', 'BQ', and 'GS' are investment profile, corruption, law and order, bureaucracy quality, and government stability respectively. a,b,c significant at $1 \%, 5 \%$, and $10 \%$ level, respectively. Standard errors in parentheses. Iterative FGLS used in estimation and heteroskedastic error structure with cross and within panel autocorrelation accounted for. 
Table 9D-2: Institutional functions, BITs and FDI flows to GCC countries

Dependent variable: log of FDI inflows per capita-interaction term

\begin{tabular}{|c|c|c|c|c|c|}
\hline & $(1)$ & $(2)$ & (3) & $(4)$ & $(5)$ \\
\hline VARIABLES & IP & C & L\&O & $B Q$ & GS \\
\hline \multirow[t]{2}{*}{ FDIFLOWSCAPITA(-1) } & $0.310 a$ & $0.226 a$ & $0.283 a$ & $0.313 a$ & $0.275 a$ \\
\hline & $(0.087)$ & $(0.085)$ & $(0.088)$ & $(0.083)$ & $(0.084)$ \\
\hline \multirow[t]{2}{*}{ INSTITFN } & 0.118 & $3.983 b$ & 1.270 & -0.988 & 1.154 \\
\hline & $(0.835)$ & (2.031) & $(1.064)$ & $(1.091)$ & $(0.975)$ \\
\hline \multirow[t]{2}{*}{ BIT } & 0.047 & $1.301 a$ & $2.724 b$ & -0.049 & $1.928 b$ \\
\hline & $(0.517)$ & $(0.297)$ & $(1.190)$ & $(0.272)$ & $(0.794)$ \\
\hline \multirow[t]{2}{*}{ BITINSTITFN } & 0.126 & $-1.147 a$ & $-1.532 b$ & 0.433 & $-0.702 b$ \\
\hline & $(0.226)$ & $(0.299)$ & $(0.733)$ & $(0.352)$ & $(0.341)$ \\
\hline \multirow[t]{2}{*}{ OIL } & $-1.533 a$ & $-1.578 a$ & $-1.877 a$ & $-1.807 a$ & $-1.564 a$ \\
\hline & $(0.518)$ & $(0.541)$ & $(0.518)$ & $(0.521)$ & $(0.498)$ \\
\hline \multirow[t]{2}{*}{ PRICE } & $0.913 b$ & $1.361 \mathrm{a}$ & $1.713 a$ & $1.539 a$ & $1.168 \mathrm{a}$ \\
\hline & $(0.417)$ & $(0.441)$ & $(0.473)$ & $(0.443)$ & $(0.419)$ \\
\hline \multirow[t]{2}{*}{ LABOUR } & $2.048 a$ & $1.921 b$ & $2.298 a$ & $2.284 a$ & $1.971 \mathrm{a}$ \\
\hline & $(0.739)$ & $(0.851)$ & $(0.700)$ & $(0.693)$ & $(0.687)$ \\
\hline \multirow[t]{2}{*}{ TRADE } & 0.659 & -1.022 & -0.836 & -0.309 & 0.264 \\
\hline & $(0.984)$ & $(0.932)$ & $(0.941)$ & $(0.970)$ & $(0.958)$ \\
\hline \multirow[t]{2}{*}{ INFLATION } & -0.122 & 0.012 & $-0.120 c$ & $-0.159 b$ & -0.113 \\
\hline & $(0.081)$ & $(0.068)$ & $(0.072)$ & $(0.076)$ & $(0.070)$ \\
\hline \multirow[t]{2}{*}{ WFDIFLOWS } & $-0.662 b$ & $-0.575 c$ & $-0.697 c$ & $-0.693 b$ & -0.545 \\
\hline & $(0.321)$ & $(0.322)$ & $(0.379)$ & $(0.344)$ & $(0.342)$ \\
\hline \multirow[t]{2}{*}{ Constant } & $-13.539 c$ & -9.169 & $-11.450 c$ & $-10.927 c$ & $-14.946 b$ \\
\hline & $(7.134)$ & $(10.309)$ & $(5.912)$ & $(6.348)$ & $(6.787)$ \\
\hline Observations & 85 & 85 & 85 & 85 & 85 \\
\hline Number of groups & 5 & 5 & 5 & 5 & 5 \\
\hline $\mathrm{HO}: \beta_{2}=0$ & - & $3.85 b$ & - & - & - \\
\hline $\mathrm{HO}: \beta_{2}=0 ; \beta_{3}=0$ & - & $19.28 \mathrm{a}$ & - & - & - \\
\hline $\mathrm{HO}: \beta_{2}=0 ; \beta_{3}=0 ; \beta_{4}=0$ & - & $21.02 \mathrm{a}$ & - & - & - \\
\hline
\end{tabular}

Notes: 'IP', 'C', 'L\&O', 'BQ', and 'GS' are investment profile, corruption, law and order, bureaucracy quality, and government stability respectively. a,b,c significant at $1 \%, 5 \%$, and $10 \%$ level, respectively. Standard errors in parentheses. Iterative FGLS used in estimation and heteroskedastic error structure with cross and within panel autocorrelation accounted for. 